\title{
Razão e Política: a Cultura como Princípio Educativo
}

\author{
Reinaldo de Montalvão de Moraes Cunha \\ Universidade Federal do Piauí (UFPI)
}

A modernidade iniciou a crítica dos antigos promovendo a ruptura entre o público e o privado, retirando do primeiro a idéia de princípios ético-morais universais, substituindo-os por interesses. Assim a modernidade vai transformar-se no auto da razão, em nome do perseguir de interesses ligados à razão instrumental. Este fato justifica a "crise " de valores que perpassa as sociedades contemporâneas. Decorrente disto, no campo da análise, da pesquisa, è de suma importância a busca de recomposição de saberes para além da razão instrumental. Neste texto, a educação é pensada pelo autor como princípio formador de vontade política, no contexto de produção democrática da cultura. Aí a educação encontra seu papel de mediador político. Categorizado como processo de desideologização, o ato pedagógico torna-se um instrumento deformação democrática da vontade política: elimna por ato de reflexão as vontades que nascem das contradições da realidade e, através de um processo discursivo, revela o lado oculto da ideologia, produzindo desejos que se manifestam em atos práticos concretos da ação política. Diante da crise dos paradigmas científicos na área da sociologia, especialmente na de política, o autor refuta os referenciais teóricos de autores que realizaram análises do tema educação na rota de exames e (re)exames das relações entre educação e estrutura econômico-social capitalista. A compreensão da conexão entre forças produtivas e relações de produção, em que o papel político da educação é analisado segundo um modelo dualista de classes sociais, não responde mais à atual realidade social e política de um capitalismo "renovado". Isso instiga um (re)pensar da educação. 
Weber introduz o conceito de racionalização buscando interpretar os reflexos do progresso técnico-científico sobre o quadro institucional das sociedades envolvidas na "modernização". Busca reconstituir conceitualmente a mudança institucional forçada pela extensão dos subsistemas do agir racional. Assim, ele conceitua como racionalização a ampliação dos setores sociais submetidos coercitivamente a padrões de decisões coletivas racionais e como domínio o espaço de racionalização instrumental, ou seja, o espaço efetivo onde a ação se dá como dominação na qual a racionalidade torna-se fator de legitimação do processo político.

Com isso, ele quer denunciar a retirada do elemento pràtico-politico como orientação da ação que tem como base a ética da convicção (a ação comunal), ou seja, a ação pela qual o indivíduo age em função de uma norma interior na consecução de um interesse coletivo.

Nos dias de hoje, a denúncia de Weber encontra fortes ecos de ressonância. Definitivamente, o sistema político contemporâneo retirou do político, entendido como poder, todo e qualquer princípio de natureza ética e moral. A eficiência técnico-administrativa (o racional-legal na terminologia weberiana) tornou-se o instrumento por excelência da política.

Mas o que Weber não pôde presenciar foi a modificação da natureza do processo de dominação social na contemporaneidade, provocada pela enorme expansão do espaço de racionalização instrumental. Aqui, nos dias de hoje, a legitimação continua sendo obtida por crenças políticas traduzidas em idéias ou teorias socialmente determinadas por relações de dominação. O surgimento, no capitalismo atual, de uma nova ideologia como fator de dominação social muda radicalmente o aparecer social. Agora a idéia aparece como sendo a própria razão instrumentan sta. Urna razão autonomizada, independente das ações humanas comandadas por um sistema autodirigido. Diferentemente das ideologias do passado, essa nova ideologia é capaz de ser, ao mesmo tempo, fator de dominação e legitimação do sistema.

Marx (1978), nos Manuscritos Económico-Filosóficos, busca analisar o desenvolvimento das forças produtivas e sua relação (recíproca) 
com o quadro institucional das sociedades envolvidas na "modernização". Para tanto, utiliza-se de um método no qual as atividades humanas representadas e criadas pelas forças humanas seguem o seu caminho, indo em direção a uma dimensão de sociedade que cada vez mais representa o próprio homem no comando e controle (mesmo que negativamente) do movimento das forças produtivas.

No entanto, o que Marx não pôde presenciar foi o fato de que o avanço tecnológico provocou um enorme desenvolvimento das forças produtivas, modificando a forma de produtividade econômica e seu processo de valorização do capital.

A vista dessa modificação, os movimentos políticos emancipatórios de hoje devem ter em mente que o progresso real da humanidade só se fará pela libertação de um processo de dominação social cujas ações emancipatórias se prendem à estrutura de um aparelho estatal autônomo, que concentra em si todos os meios capazes de controlar e regular os processos sociais. Deste modo, a essência subjetiva, manifesta da subjetividade humana, e a praxis, que se efetua através da fala (Arendt, 1991), ficam tão presas à dinâmica da estrutura estatal quanto no passado se prendiam ao movimento da propriedade, no qual a história da indústria e o seu modo objetivo de existência representavam a história do movimento das forças essenciais humanas.

Ora, uma realidade em movimento provoca necessariamente mudanças de ordem conceitual. Torna-se necessário reformular a interpretação dos reflexos do progresso técnico-científico sobre o quadro institucional das sociedades envolvidas no processo de modernidade, pensada pelos clássicos, para (re)pensar a categoria de democracia.

\section{Arendt: poder e concepção aristotélica de política}

Arendt, em A Condição Humana ( 1991 ) e Entre o Passado e Futuro ( 1972), tece considerações acerca da vida ativa, constituída de três atividades 
humanas básicas, e designa-as por ação, trabalho e labor. Visa, ao elaborar conceitualmente estes três tipos de ação, buscar elementos analíticos capazes de instrumentalizá-las na compreensão da concepção política grega. Para ela, a ação, como praxis que se efetua através da fala (lexis), tem a ver com a compreensão do mundo; o trabalho, como autoprojeção humana (não entendido como sujeição ou alienação), tem a ver com a capacidade humana de produzir um mundo, configurado em artefatos, que se põe para além do próprio homem; e o labor tem a ver com a produção de um mundo material de coisas que visa à subsistência da espécie.

Assim, a ação se caracteriza pela pluralidade (essência da democracia) e é o instrumento por excelência da política; o trabalho, pela fabricação, através do qual o homem torna-se capaz de fazer (construir) um mundo de coisas ao seu redor; e o labor tem a ver com metabolismo, com a capacidade do homem de recompor suas energias vitais através de atividades ligadas à subsistência.

Com esse instrumental conceitual, Arendt vai puxar o fio pensante da tradição, buscando resgatar a esfera pública destruída pelo moderno. Sua análise prioriza a relação público/privado como modo de organização da vida social e política do antigo (tendo como base a organização da polis) e seu processo de desenvolvimento para o moderno.

A distinção público e privado, marcante na Antigüidade, dava-se pela nítida separação daquelas duas esferas. No espaço público, os homens realizavam atividades pertinentes ao entendimento do mundo que era comum aos homens. Assim, a esfera pública (a polis) constituía-se no espaço de atividades pertinentes à compreensão do mundo, que se realizava através da fala (lexis). Como esfera pública, este era o local no qual os homens encontravam-se, viam-se, falavam-se e se entendiam acerca do mundo comum ao seu redor. $\mathrm{O}$ discurso, como ato de entendimento do mundo, era o instrumento (medium) que permitia a recordação do fato histórico. A ação, como atividade humana, preservando os corpos políticos, criava as condições para a lembrança da história. A ação, como a atividade 
mais digna do homem, punha-se, então, para além de uma simples atividade de labor (metabòlica).

Contraposta à esfera pública, situava-se a esfera privada do lar (oikiá). Essa esfera se constituía no espaço de atividades pertinentes à subsistência humana (espaço da economia, do lar). Como esfera privada, era o local onde os homens cuidavam da sua sobrevivência, das necessidades. $\mathrm{O}$ fazer (das mãos), concebido como laborar, interagir com a natureza para dela retirar o seu sustento, era o instrumento \{medium) que permitia a recomposição das energias vitais. $\mathrm{O}$ labor, como atividade humana, preservava os corpos biológicos, criando as condições para a sobrevivência da espécie.

Essa surpreendente análise de Arendt vai permitir-lhe identificar a concepção de política em Aristóteles, que apenas traduz a opinião pública da época, possibilitando sua comparação com a concepção de política no moderno, bem como suas rupturas e inversões.

Se nos detivermos na análise e na perplexidade que ela nos traz, podemos verificar que apolítica fio moderno se coloca como contraponto da concepção aristotélica da política no antigo.

Se entendermos política como poder, como relações de dominação características de relações assimétricas entre os homens, tais relações não eram constitutivas do modo de interação próprio da esfera pública no antigo. As relações de poder, como constitutivas da política, efetuavamse, no antigo, na esfera privada (oikia). Ali, sim, as relações eram assimétricas, próprias de uma sociedade com desigualdades sociais. Nesse espaço, davam-se as relações de poder, que se caracterizavam pelas relações de dominação entre o pater familiae (patriarcas) e seus escravos (responsáveis pelas condições de sobrevivência de seus senhores).

O contraponto da esfera privada (que possui conteúdos da política no moderno) é a polis constituída como esfera pública. Ali, sim, as relações eram simétricas, próprias de uma sociedade de "iguais" (ou dos cidadãos atenienses, os "mais iguais"), que estabeleciam entre si relações políticas, 
entendidas como atos de compreensão do mundo circundante, na busca do interesse comum cuja compreensão dava-se pela linguagem. Política era comunicação por consenso, como ato supremo de um engrandecimento dos feitos humanos, através da qual se estruturava a polis ou a cidadeestado. Não fazia parte, portanto, do conteúdo da política o poder. Nem tampouco eram admitidas a violência, a coerção e a manipulação da consciência dos cidadãos com relação às verdades que o mundo em comum revelava.

Arendt, então, prossegue sua análise no intuito de captar o político no seu desenvolvimento do antigo ao moderno, em que subjaz, nas suas obras acima citadas, a idéia cara ao seu pensamento. Somente através do resgate dos princípios éticos e morais suprimidos da política no moderno poderemos buscar o renascimento de sua esfera pública, impedindo a volta de dois fenômenos totalitários - nazismo e stalinismo - que tanto assustaram o século XX. Um século chamado por muitos como o século do apogeu da modernidade.

Para Arendt, foi através do fenômeno da ascensão social que se deu aquela inversão, a qual consistiu na ascensão da administração caseira como uma "economia do lar" que, com suas respectivas atividades ampliadas, vai assumir o papel da esfera pública. Na passagem do antigo ao moderno o espaço do lar (oikia) se agiganta e fagocita o espaço publico (polis). Este fenômeno vai dar-se progressivamente. Começa pela absorção da família por grupos sociais correspondentes, instiga o nascimento do Estado moderno como fórmula política consonante a essa ascensão, entendendose este como um agregado social que mantém "relações políticas" e, por fim, surge a fórmula última do Estado nacional no qual a burocracia vai proceder à administração, transformando a atividade de governar numa mera administração de um estado de coisas.

Neste aspecto ela é incisiva. Na Antigüidade, as leis se faziam em espaços neutros, ou seja, na "parede" que separava com nitidez a esfera pública da privada. Tendo a esfera pública necessidade de leis mínimas 
em virtude dos conflitos serem reduzidos, e esta era a característica intrinseca da polis, as leis muitas vêzes eram encomendadas. Esses espaços neutros (das leis), concomitantemente com a ampliação do social, obturaram-se para o interior $d a$ polis, configurando-se no moderno como constituições de seus Estados.

$\mathrm{O}$ resultado deste fenômeno foi o conformismo. Sob um ordenamento jurídico coercitivo, como elemento básico de coesão social, o moderno substitui a ação livre e criativa das vontades individuais, proclamando a necessidade de se evitar a desintegração social. Assim, Estados modernos esperam de cada um de seus membros (esta é a base da teoria do Estado do "bem comum") um certo tipo de comportamento. Para tanto, a sociedade é colocada sob um ordenamento jurídico com leis tendentes a "normalizar" relações sociais que se adaptam a padrões comportamentais, abolindo toda ação espontânea ou reação inusitada.

Constatada aí, na análise acima, a contradição inerente à concepção de política aristotélica (a liberdade, como valor democrático, como précondição da política, começa quando relações de poder presentes na oikia deixam de modo abstrato de existir), um paradoxo que Arendt não desconsiderou sobrepõe à análise o recurso metodológico de ela se tornar um instrumento poderoso de crítica aos modos de organização política do moderno.

Enfim, Arendt faz uma crítica radical aos atuais Estados democráticos da modernidade. A nosso ver, uma questão nuclear, que vai nortear seus objetivos, é a possibilidade que a crítica permite: a construção de uma sociedade (no plano da utopia) na qual a política como comunicação vai tornar-se um instrumento de resgate de uma esfera pública destruída pelo moderno.

De fato, o espaço público no moderno, como exercício efetivo da política, não tem mais como no antigo as características de sua ação estatal fincadas na compreensão do mundo e na forma coerente de construí-lo. Erigiu-se a ação do labor como instrumento da política, e esta perdeu sua 
"sabedoria". A ação estatal no moderno caracteriza-se essencialmente por uma eficiência técnico-administrativa operativa, em que a racionalidade, como "ideologia" da técnica, torna-se o fator preponderante dos processos de legitimação, aprofundando o domínio. Política é manipulação, coerção e violência institucional.

Política não é mais a ação mediada pelo discurso, pela palavra como compreensão de um mundo comum, no interior do qual os homens interagem formando-se como sujeitos do processo político, reais construtores de suas instituições. Pelo contrário, o discurso comunicativo, como ato de entendimento do mundo que se revela como verdade, tornouse instrumento por excelência de manipulação das consciências.

Esfera pública não é mais espaço de opinião. A ação como discurso é banida para o privado em seu real significado de intimidade. A palavra, como ato de entendimento, é cassada e o espaço público se destrói pela perda do significado da política. Como conseqüência de uma comunicação cassada, as pessoas tornam-se estranhas ao seu mundo, isolam-se, despolitizam-se e não conseguem lutar pelos seus direitos. O moderno, na verdade, se caracteriza pelo enfraquecimento progressivo da sociedade civil como espaço de formação de opinião pública.

\section{Habermas: o agir comunicativo e o renascer da esfera pública}

Habermas (1983) tem em mente a proposta de Arendt. Se o privado na organização sociopolítica ateniense era o espaço de labor, de relações assimétricas, de poder e de coerção, é sensato propor o ressurgimento de uma esfera pública, no moderno, como espaço de interação ou comunicação desimpedida de seus constitutivos de poder, coerção e domínio. Julgamos estar aí o princípio inspirador de seu modelo do agir comunicativo. Um modelo que ele mesmo vai chamar de contrafatual e utópico.

Habermas toma como ponto de partida da sua análise a reformulação do conceito de racionalização weberiano. Como sabemos, 
em Weber, a racionalização se dá quando as ações sociais assumem um sentido racional instrumental. Um sentido no qual a ação é compreendida como busca de interesses individuais e imediatos utilitários. Daí, então, retira-se o conceito de domínio. Este se dá como exercício efetivo da ação política, como um espaço de racionalização instrumental.

Assim, o Estado e sua política funcionam como exercício de dominação, ou seja, um espaço de racionalização estruturado numa ordem legítima, incorporada pelos agentes como regra normativa de conduta (padrão comportamental). Neste sentido, para Weber, o poder como domínio se legitima através da racionalidade como fator de crença política.

Habermas vai retomar e reelaborar as inspirações arendtianas a partir daí. Ele vê, então, na racionalidade comunicativa o instrumento necessário para se libertar do poder-domínio. Reelabora a contraposição público e privado em Arendt, tomando como par conceitual a interação, modo de um interagir dos homens como ato de compreensão do mundo, análogo ao da polis, e trabalho, modo de um interagir dos homens com a natureza mediada por instrumento técnico-operativo. Ele abandona a diferença sutil existente em Arendt entre labor e trabalho.

Por trabalho ele vai entender um agir racional com respeito a fins, ou seja, como agir instrumental e como escolha racional, ou a combinação de ambos. $\mathrm{O}$ agir instrumental orienta-se por regras técnicas com base no saber empírico. Implica prognósticos condicionais acerca dos fatos sociais ou físicos. Predições que podem se revelar corretas e incorretas. Realiza objetivos em condições dadas e organiza meios adequados como controle eficaz da realidade. A escolha do comportamento racional ou a escolha racional é dada por estratégias (agir estratégico) com base no saber analítico, e tem sua derivação a partir de regras de preferências no interior de um conjunto de valores. Constitui-se, portanto, um processo lógico-dedutivo realizado com auxílio de valores e máximas. E dependente de uma avaliação correta das possíveis alternativas de comportamento. Enfim, o trabalho tem sua vigência em regras técnicas e estratégias (Habermas, 1983, p.321). 
Por interação Habermas vai entender um agir social ou comunicativo, regido por normas consensuais revestidas de obrigatoriedade, que definem expectativas de comportamento recíproco. As normas devem ser entendidas e reconhecidas, pelo menos, por dois agentes, e estão fundamentadas no entendimento das intenções e asseguradas pelo reconhecimento universal das obrigações.

Separando e contrapondo dois modos diferentes de interação humana, o interagir social, com fins de entendimento do mundo, e o trabalho, um interagir com fins de subsistência, Habermas vai buscar nas teorias da linguagem uma outra racionalidade, constituída de uma ordem epistemológica diferente das ciências positivistas.

Para ele, as atividades humanas encontram sua solução como um problema de coordenação da ação. Em última análise, trata-se, então, de distinguir nos dois tipos de interação — "interação" e trabalho — os mecanismos presentes de coordenação da ação.

o agir estratégico, a linguagem natural é utilizada como meio para transmitir informações. Sendo assim, seu efeito de coordenação deriva da situação da ação e da influência que os atores exercem uns sobre os outros. A aprendizagem das regras, que permitem este tipo de ção, vai dotar os indivíduos de habilidades e qualificações. No agir comunicativo, a linguagem natural é utilizada como fonte de integração social pela sua/orça consensual de entendimento, que se faz de maneira não coercitiva. Logo, seu efeito de coordenação se encontra na força do argumento da fala, que não pode ser realizada com dupla intenção, quando se visa chegar a um acordo. A interiorização das normas que regem esse tipo de ação vai dotar os atores de estruturas de personalidades (Habermas, 1990, p.71). Em síntese, Habermas busca a construção de um "Estado antecipado" como esforço organizacional de instituições democráticas, no qual a formação do ator coletivo, sujeito real do processo político, se dá por um consenso comunicativo, como ação intencional dos indivíduos. Busca, enfim, a reconstrução contemporânea de uma esfera pública, nos 
moldes da polis, na qual a palavra ou a comunicação como verdade volta a dar significado à política.

$\mathrm{Na}$ linha das intuições de Arendt, seu modelo de sociedade contrafatual e utópica separa nitidamente a esfera privada da esfera pública. Nesse seu modelo, de natureza presentiva, o quadro institucional consiste no subsistema político, que se organiza como um mundo de um viver sociocultural, no qual as ações se orientam por uma racionalidade comunicativo-simbólica. Por outro lado, o quadro do trabalho consiste num subsistema social que se organiza como um mundo na sua forma econômica. Aí as ações humanas se orientam por uma racionalidade económico-utilitaria. Trata-se, enfim, de uma sociedade que vai desenvolver esforços políticos que vão orientar a organização dos espaços público e privado, de acordo com as racionalidades que lhes são específicas e que darão um sentido prático que orienta a ação política.

Nessa separação nítida da esfera do público e do privado, constatase um engano de Habermas. Distinguindo duas racionalidades que geram diferentes conhecimentos, que vão orientar ações sociais, ele vai abstrair dos atores concretos as condições sociológicas de formação econômica e dominação social presentes na realidade ${ }^{1}$.

Um equívoco de Habermas - sua insistência em distinguir tipos de racionalidades e diferentes conhecimentos, o que, por sua vez, vai abstrair dos atores concretos que se emancipam as condições sociológicas de formação econômica e de dominação social presentes na realidade - sobrepõe à sua análise a intenção que a crítica permite. Habermas aponta para a possibilidade de se buscar um modelo normativo da política, cujo conceito de legitimação não passe pelo poder-domínio, mas, sim, pela necessidade de aboli-lo.

\footnotetext{
${ }^{1}$ Reis (1984), em um dos seus trabalhos, desenvolve uma análise critica a esta posição de Habermas. Utilizandose das análises de Piaget, afirma que as condições para a ação racional se superpõem, em grande medida, não apenas às condições para a ação de natureza instrumental, mas também para a comunicação, a colaboração, a ação solidária e moral. Deste modo, a ação racional não tem como substrato último a excelência da operação concreta do trabalho.
} 
Reconhecendo, portanto, a genial intuição de Habermas, que, ao reformular o conceito weberiano de racionalização, busca a eliminação de formas de legitimação com ingredientes de domínio, nos dispomos a explorar este problema aí evidenciado. Um problema político que necessariamente terá que ser tratado na sua relação com a emancipação humana. Contudo, o faremos sem abandonar as trilhas de intuição de Arendt e Habermas.

\section{Normatividade e vida política}

A diferença básica entre Hegel (1983) e Kant (1991) está na constatação de que, para o primeiro, a verdade que a filosofia procura conhecer não está de modo algum colocada na forma de teses dogmáticas fixas que, uma vez descobertas, basta guardar na memória. Hegel não aceitava, pois, a existência de uma consciência anterior, fundamentada a si mesma, produzindo a realidade. Para ele, a verdade reside no próprio processo do conhecimento, ou seja, no conjunto de representações de uma época, de uma sociedade como produto de uma consciência real (o real é o racional e o racional é o real). Representada de forma imediata, a realidade existe e está em constante movimento em busca de seu fim: $a$ idéia absoluta.

Então, para Hegel, a consciência real só se forma como reflexão após a consciência natural contingente ter produzido um conhecimento que ele chama de imediato. Consciência real, para Hegel, é aquela que executou um movimento teórico de reflexão. Entretanto essa consciência que produz um conhecimento em primeira mão é ilusória (falsa), porque ela contém em si o "germe" de sua contradição, que executou um primeiro movimento teórico de negação. A partir de então, a consciência vai em busca da superação da sua contradição (a negação da negação), em direção ao seu fim: a ciência como verdade absoluta. 
O que em Hegel se inicia como uma crítica imanente a Kant transforma-se, no fim, em uma negação abstrata. A teoria do conhecimento produz-se em círculos e deve curar-se da sua falsa consciência para chegar à consciência de si mesma (Habermas, 1987).

Para Kant, a consciência real forma-se como reflexão antes da consciência natural contingente ter produzido um conhecimento. Para ele, quando se realiza pelo pensamento um movimento teórico de reflexão, produz-se, primeiro, um entendimento da realidade a priori — um conceito. Este, posto na relação com a experiência, produz o conhecimento, a realidade. Essa consciência anterior que produziu a realidade existe em si mesma (consciência prototípica) e é anterior ao seu resultado. Consciência real, para Kant, é aquela consciência, fruto da razão em si mesma, que produziu pela percepção dos fenômenos a consciência contingente da realidade.

Contra essa consciência anterior, como um a priori do entendimento da realidade, Hegel dirigiu sua crítica. Para ele, é o mesmo que aprender a nadar sem entrar na água. Entretanto, essa consciência anterior não deixa de ser a mesma consciência real — a verdade absoluta hegeliana. A diferença é que em Kant a consciência real precede a produção da realidade e em Hegel ela é procedente da produção da realidade. Para o primeiro, o princípio da crítica torna-se apenas uma dúvida incondicionada, dúvida essa que se resolve no fundamento da razão e que não precisa de fundamentação. Para o segundo, a consciência que se critica não faz parte da dúvida metódica. Ela se constitui em um medium através do qual a consciência se desenvolve (superando as contradições) como consciência de si.

Derivam, pois, de Kant e Hegel os conceitos acerca da consciência falsa. Enquanto que, para o primeiro, consciência falsa é aquela que executou um movimento teórico de reflexão, que não guarda relação com a experiência, com o mundo sensível dos fenômenos \{uma ilusão, uma ficção), para o segundo, consciência falsa é aquela que executou um 
movimento teòrico de reflexão e produziu uma consciência contingencial imediata \{uma realidade ilusória, falsa).

Contra a idéia do absoluto e do movimento do espírito surge, da critica do idealismo hegeliano, o materialismo histórico. Era preciso, segundo Engels ( 1961 ), substituir o culto do homem abstrato (uma alusão à obra de Feurbach) pela ciência do homem real e de seu desenvolvimento histórico. A primeira geração dos jovens hegelianos passa, então, a criticar na obra do mestre a prevalência do atemporal e do necessário sobre o mutável e o causal.

Criticam, portanto, em Hegel, a moldura idealista do conceito da razão, um movimento do espírito no qual este era compreendido dialeticamente como um espírito que caminha através da natureza e da história. Para Marx e Engels (1961), o processo ininterrupto de uma realidade em movimento, do vir-a-ser e perecer, não é absoluto, definitivo. Esse processo é uma ascensão infinita do inferior para o superior como movimento teórico da matéria, ou seja, pelo reflexo desta no cérebro do homem ou naquilo que se pode chamar de razão. Deste modo, Marx divergia de Hegel no método e não no conteúdo. Enquanto o mestre dava primazia ao movimento do espírito, Marx privilegiava, como método de análise, o movimento da matéria.

A primazia, por uma questão de método, não se situa na razão, no pensamento puro, mas na praxis, enquanto atividade humana na qual o homem pensa a realidade (teoria) e o modo correto de seu agir no mundo (prática). Neste caso, espírito e matéria (realidade), uma coisa só, caminham através da natureza e da história.

Marx retoma o conceito de praxis na polis, a ação em Arendt, como pensamento contemplativo, como ato de entendimento do mundo, mediado pela linguagem (lexis) e o articula com o labor, como ação humana — um fazer na relação com a natureza —, como ato de sobrevivência no mundo, mediado por instrumentos materiais. Ele não distingue a ação humana mediada por instrumentos materiais \{o agir instrumental) da ação 
humana mediada pela fala (o agir comunicativo). Na verdade, ele articula a ação de pensar o mundo e entendê-lo através da linguagem (teoria) com a ação de fazer o mundo e transformá-lo através de atividades laborais (prática). Metodologicamente, privilegia a prática (as ações de natureza instrumental). São essas ações que vão se revelar, para ele, capazes de promover a emancipação humana, a qual se realiza como praxis, como atividades humanas conscientes da classe proletária.

Para Marx, então, a consciência real é aquela que executou um movimento teórico de reflexão na Junção com as ações humanas que põem em movimento as forças produtivas. Deste modo, a consciência real vai formar-se enquanto praxis, que produz representações em estruturas sociais e modos de produção determinados. Entretanto, as representações imediatas, que contêm em si as suas contradições, vão produzir-se em formas que podem aumentar ou diminuir a transparência de uma sociedade. Assim, para ele, a consciência falsa é uma das modalidades de consciência da realidade social, na qual as interações humanas produzem aparências.

Nossa posição teórica segue a argumentação de uma crítica imanente a Kant, iniciada por Hegel, e vai na direção de uma critica imanente a Marx.

Sustentamos que as ideologias, entendidas e compreendidas por Marx, não se podiam explicar como falsa consciência ilusória de produtos racionais elaborados pelos homens através de conhecimentos empíricos (o privilégio da prática). E nem se realizavam na relação existente entre teoria e prática como praxis social una (como privilégio de uma orientação política dada pelo agir instrumental). Nos opomos a um esquema reducionista hegeliano compreendido de forma negativa.

Em Marx (1981), as ideologias são idéias ou teorias socialmente determinadas pelas relações de dominação entre as classes. Assim, a determinação dessas relações resulta no processo de interação humana numa falsa consciência, ou seja, os indivíduos (ou a classe) têm na descrição 
falsa da realidade uma orientação política para sua ação. Trata-se, enfim, de delinear um "sentido" para a ação politica, diante de urna dada situação, retirado de um conjunto de teorias (empiricamente demonstráveis) e valores (de natureza simbólica).

Entretanto, tal sentido se torna abstrato por nao ter o ator coletivo (a classe) uma "consciência primeira" que o oriente na sua ação. Sendo assim, ele "entra" na historia como ator que não tem de inicio urna consciência de sua ação. Constata-se aí uma relação de incompatibilidade entre um sentido dado a uma ação e as relações recíprocas (dialéticas) entre conjunto de teorias como juízos de asserções de fatos e máximas como juízos de valor. Temos, então, um esquema hegelianista compreendido de forma negativa e abstrata.

Para nós, assim como em Marx, a consciência real é aquela que executou um movimento teórico de reflexão na junção com as ações humanas que põem em movimento as forças produtivas. Deste modo, a consciência real vai formar-se enquanto praxis que produz representações em estruturas sociais e modos de produção determinados. Entretanto, as representações imediatas contêm em si os "germes" das contradições da realidade, porque são resultados de falsas motivações (ou vontades) que vão dar um sentido pràtico-politico às ações humanas no contexto duplo de racionalidades, e não porque elas já estão contidas na realidade "fatalisticamente", numa forma abstrata e negativa.

Retiramos, portanto, da noção de ideologia em Marx seu caráter de falsidade (entendido no seu sentido objetivo), mas retemos o significado forte da ideologia, pensada por ele, enquanto orientação para a praxis, que não pode e nem deve nunca sobrepor interesses de poder (coerção, manipulação e violência) aos interesses emancipatórios, como forma de orientação ética e moral para o exercício político, sobretudo da vida pública.

A consciência real forma-se produzindo representações em estruturas e modos de produção determinados como resultado de praxis 
social de natureza dupla — praxis social dupla (como privilégio de urna orientação politica dada tanto pelo agir instrumentai quanto pelo comunicativo). A consciência natural contingente produz um conhecimento imediato executando dois movimentos teóricos de reflexão de natureza distinta, a) um movimento interno do pensamento, realizado pela razão como produto de um processo cognitivo. Essa razão produz, então, conhecimentos sistematizados na forma empírica, que se concretizam em ações operacionais concretas com características operatórias e instrumentais (praxis do tipo teórico-técnico); b) um outro movimento interno do pensamento, realizado pela razão como produto de um processo de natureza não cognitiva, através do qual a razão, na sua natureza prática, sistematiza formas interpretativas de valores que se concretizam em ações de obediência às normas sociais existentes, reconhecidas como legítimas, porque são reconhecidas por todos intersubjetivamente (praxis do tipo teórico-prático).

A consciência real forma-se como um processo de análise interpretativa racional e empírica da realidade. Entretanto, as representações humanas, como ideologias, formam-se por análises erráticas da realidade, como produto de vontades humanas e não porque já nasceram assim, numa forma abstrata de negação da realidade. Daí que as representações humanas imediatas, contendo falsas motivações (falsos sentidos para a orientação de ação política), vão formar $a$ consciência falsa, que é aquela que se forma, numa realidade conflituosa, como produto de vontades humanas que nascem das contradições da realidade, ocultando-a.

O caminho da natureza e da história dos homens não se faz por um movimento exclusivo da matéria, onde esta age "por sobre a cabeça dos homens" (produzindo ações não-intencionais). Esse caminho se faz também por um movimento do espírito, capaz de compreender o mundo e retirar dele um sentido prático através de julgamento de valores com validade de significados. 
Nossa argumentação buscou, até aqui, constatar um equívoco de Marx (e Habermas muito bem o aponta). Esse equívoco consiste no fato de que Marx, nas suas análises, não distingue a ação criadora do homem, através da qual ele produz um mundo artificial das coisas, como necessidade prática de conservação da vida material (a atividade econômica), da ação criadora do homem, através da qual ele produz uma interpretação racional de seu mundo vital, como necessidade prática de conservação da vida nos seus aspectos não-materiais (atividade intelectual ou "espiritual").

Divergimos de Marx, mas esta divergência não é de conteúdo, mas de método. Trata-se apenas de "desgarrar pelo pensamento" (uma alusão a Hegel e agora a Marx) o processo de interação dos homens, realizado pela fala como forma de comunicação, no qual a linguagem é compreendida como instrumento de poder. Essa linguagem exerce também um papel importante na formação da realidade, que se faz na junção das ações humanas que põem em movimento as forças produtivas.

Decorrente de tudo isto, a compreensão das ações sociais que se realizam no contexto de racionalização toma um único sentido, de acordo com a natureza dupla da razão.

Julgamos que Weber (1982) tenha se equivocado quando deu um tratamento analítico à ação social, caracterizando-a de caráter exclusivamente instrumental. Para nós, a ação social é de natureza dupla. Ela se constitui como ação de natureza instrumental dependente de conhecimentos a posteriori, empiricamente tratáveis, mas é também de natureza simbólica, normativa, dependente de conhecimentos a priori. Deste modo, vamos entender, diferentemente de Weber, o conceito de racionalização: racionalização é um processo no qual as ações sociais tomam um sentido racional instrumental e ao mesmo tempo normativo.

Para Weber, a racionalização dá-se quando as ações sociais tomam um sentido de racionalização instrumental, que implica uma racionalidade do domínio. Uma racionalidade capaz de fazer do crescimento das forças 
produtivas, ligadas ao progresso técnico-científico, o fundamento da legitimação do domínio. Para Marx, ao contrário, esse processo de racionalização era visto, embora de forma critica, como potencial de emancipação humana. Ele via na racionalidade de sua época, traduzida em forças produtivas ligadas ao progresso técnico-científico, um instrumento potencial de libertação desde que depurada, por uma praxis revolucionária, de seus pseudo-elementos de legitimação democrática de uma sociedade capitalista.

Habermas (1983) tenta recuperar, no seu modelo de reconstrução teórica de "comunicação pura", o conceito de racionalização de Weber, preservando o que ele chama de intuição de Marx. Para ele, a emancipação humana diante de uma racionalidade de domínio não se dá como Marx pensara. Este se equivocara, pois não conseguiu compreender a interdependência na dialética das forças produtivas e condições de produção, ou seja, o modo de expansão de um saber de natureza técnica e a idéia de um acesso humano a uma consciência de si não distorcida por uma ideologia.

No dizer de Reis (1982, p.189), Habermas, ao reformular o conceito de racionalização em Weber, insiste na separação nítida entre os contextos de trabalho e interação. Estabelece, assim, uma distinção entre diferentes tipos de racionalidades e conhecimentos. Assim o fazendo, ele não reconhece a existência da relação entre meios e fins no comportamento do ator social que se emancipa. Não reconhece, enfim, a natureza do comportamento do ator social, que é ao mesmo tempo instrumental e subjetiva. Habermas desconhece o papel da ação estratégica claramente intermediária entre interação e trabalho. Reis chega inclusive a admitir estar contida nessa separação o "inquestionável" fracasso de Habermas em sua proposta epistemológica central. Nessa equívoca concepção de racionalidade, Habermas vai abstrair dos indivíduos concretos que se emancipam as condições sociológicas presentes na realidade. 
Podemos dizer, então, que nossa intencionalidade atingiu seu objetivo: buscamos recuperar, com base na crítica de Reis (1984), as idéias de Habermas, nas trilhas de Arendt, acerca da indispensável necessidade de se propor um modelo teórico que busque o ressurgimento da esfera pública que o moderno destruiu.

Ao admitirmos um conceito de racionalidade única, que se realiza por uma razão de natureza dupla, restabelecemos a relação entre os meios e fins que objetivam o comportamento de um ator social, nos contextos de trabalho e interação. Voltamos assim a um conceito de praxis única.

No entanto, essa volta não implica o entendimento de um mundo racionalizado numa forma instrumental. Para nós, a praxis social não é entendida como produção de ações humanas simples e de caráter instrumental. Ela é efetivada e se dá como produto de ações sociais derivadas da experiência, mas se realiza por uma ação de natureza dupla. Desta maneira, à medida que as ações instrumentais ocorrem, acontecem também as ações de caráter normativo (de natureza comunicacional e simbólica).

Em decorrência, os processos de individuação e socialização ocorrem de tal modo conexos que é na formação individual (estrutura cognitiva intelectual) que se forma agênese da ação socializada. À medida que os indivíduos aceitam como válidas (intersubjetivamente) normas interpretativas da realidade realizadas por outros, vão-se formando as condições necessárias para o surgimento das vontades humanas que se tornarão coletivas. Isto significa que os atores vão-se constituindo por intermédio de uma consciência real que se forma pelas condições sociológicas presentes na realidade (formação econômica e processos de dominação social existentes).

Somente assim a expressão autêntica de identidades individuais pode ser assumida lúcida e livremente na articulação com as identidades coletivas em sua profundidade histórica. Deste modo, as vontades coletivas formamse na sua conjunção com as identidades individuais, que se realizam na sua 
junção com as forças produtivas. Isto porque as ações humanas são de caráter instrumental e, ao mesmo tempo, normativo.

\section{O (re)pensar do caráter de dominação social na modernidade}

É na relação do quadro do trabalho, espaço no qual os homens controlam as forças da natureza para delas retirar suas necessidades de sobrevivência, e do quadro institucional, espaço de interação no qual os homens ajustam as relações entre si, construindo formas sociais de distribuição da riqueza social, que vamos apreender as mudanças (readaptações) ocorridas nas diversas construções históricas das estruturas políticas capitalistas dos países ocidentais.

O crescimento das forças produtivas no século XIX acrescentava ao quadro institucional uma expansão do espaço de racionalização, que se manifestava como um domínio inconteste do capitalismo no seu tempo. Essa expansão da racionalidade de dominação, Marx (1961, p.245) a entendeu como relações de produção:

Os homens nunca renunciam àquilo que já adquiriram; mas isto não quer dizer que nunca renunciam às formas sociais sob as quais adquiriram determinadas forças produtivas. Muito ao contrário. A fim de não serem privados dos resultados obtidos c para não perderem os frutos da civilização, eles se vêem obrigados, a partir do momento em que a forma de seu comércio não corresponde mais às forças produtivas alcançadas, a modificar todas as suas formas tradicionais.

Nesta passagem de Marx, que corresponde a um dos pilares de sua teoria sociológica, ele chama a atenção para a inversão de um processo político que estava ocorrendo no capitalismo. Nas sociedades "tradicionais", pré-capitalistas, a legitimação, consonante a uma forma de dominação social, fazia-se através de interpretações cosmológicas do mundo, devido ao nivel de desenvolvimento de suas forças produtivas. Com o desenvolvimento 
dessas forças, ampliou-se o espaço de racionalização e, conseqüentemente, a necessidade de novas interpretações do mundo ${ }^{2}$. Deriva daí, também, a exigência de novas relações entre os homens e a readaptação do quadro institucional, através da construção de novas formas sociais. Ao perecerem as antigas formas de domínio, o espaço ampliado da razão instrumental exige para si o papel de dominação.

Marx identificara a nova forma de dominação social do capitalismo de seu tempo: se antes os fundamentos do domínio eram imediatamente políticos e só mediatamente econômicos, agora a legitimação que fundamentava o domínio era de imediato econômica. A partir daí, Marx elabora, então, a crítica da ideologia burguesa em sua nova forma de economia política. Para ele, o Estado de Direito burguês, enquanto "superestrutura", se subordinava ao mercado privado. Sua teoria do trabalho revela a aparência (crença ideológica) de liberdade na troca dos equivalentes. Evidencia a relação de violência institucional que subjaz à relação do trabalho assalariado, compreendida, na forma de relações de produção, como direito jurídico privado (direito de propriedade).

Habermas (1983) aponta, em Técnica e ciência enquanto "ideologia ", dois fenômenos ocorridos no desenvolvimento do capitalismo que alteraram significativamente, desde a época de Marx, a conexão entre as forças produtivas e as relações de produção.

Desde os fins do século XIX, os fenômenos do intervencionismo estatal e da interdependência entre pesquisa e técnica vêm perturbar aquela constelação entre o quadro institucional e o trabalho (subsistema da ação racional instrumentalista).

\footnotetext{
${ }^{1}$ Estamos entendendo os conceitos de racionalização e domínio na forma em que Max Weber os concebeu. Entende-se por racionalização um processo no qual as ações sociais tomam um sentido racional instrumental que sempre caracterizou, para ele, a história da modernidade. Por racionalidade de dominação ou domínio entende-se a racionalidade capaz de fazer do crescimento das forças produtivas ligadas ao progresso técnico o fundamento da legitimação social. Ver Cohn (1989), especialmente o texto cinco de Weber, "Religião e racionalidade econômica".
} 
Com o surgimento do intervencionismo estatal uma importante mudança ocorreu. Emergiu, como uma nova forma social, um aparelho estatal autônomo com relação ao mercado, com fins de garantir a estabilização e o crescimento econômico pela eliminação dos riscos que vinham ameaçando o sistema. Nesse sentido, quando o fenômeno do intervencionismo vai se consolidando como um fato histórico do século XX, um aparelho estatal "renovado" vai se constituindo complementarmente à base da produção. Este visa, em última análise, à estabilização da economia pela compensação de disfunções ocorridas no processo de troca de equivalentes. Uma economia efetivada por um desenvolvimento endógeno, regulada por uma "mão invisível" (uma alusão a Adam Smith), não era mais congruente com os princípios liberais de uma sociedade burguesa.

Esse "novo" quadro institucional surge ofertando um programa de substitutivos. Nele, a orientação não se dá mais pelas conseqüências sociais de um mercado, mas por orientações capazes de preservar as condições estáveis de um sistema global como garantia de segurança social (pleno emprego) e performance técnica; como garantia de status, de acordo com o rendimento individual, bem como estabilidade no emprego e vencimentos.

Com o fenômeno da interdependência entre pesquisa e técnica ocorre também uma outra significativa mudança. Na verdade, os esforços institucionais que incentivam a pesquisa, visando aumentar a produtividade, através de inovações tecnológicas, sempre existiram no capitalismo, porém numa forma natural de crescimento. Na contemporaneidade, as pesquisas são encomendadas em grande escala e passam a não objetivar de imediato a produção econômica. Constituem-se, por assim dizer, reservas de tecnologias retrabalhadas e, só mais tarde, se colocam como aplicáveis. Exemplo disso encontramos na articulação de pesquisas encomendadas pelo setor militar, onde as informações técnicas que favorecem esse setor são repassadas, posteriormente, para os setores de produção de bens civis (Habermas, 1983, p.329). 
Esta interdependência permitiu um avanço extraordinário do progresso técnico, a ponto de transformar a técnica e a ciência contemporânea na principal força produtiva. Ora, isto traz como conseqüência relevante o fato de a produtividade, que determina o acúmulo do capital, não se fazer mais em função básica dos produtores imediatos. Neste ponto é importante frisar que a força de trabalho dos produtores imediatos era a única fonte de mais-valia considerada por Marx.

Para Marx, a força de trabalho do produtor imediato, medida pelo tempo de trabalho socialmente necessário, é responsável por uma produtividade que se realiza no contexto de um desenvolvimento das forças produtivas. A produtividade é dada peia força de trabalho capaz de produzir mais do que o necessário em quantidade e qualidade, com fins de preservação da vida, na articulação com as relações de produção. Entretanto, Marx via essas relações constituídas pela propriedade econômica das forças produtivas. Contudo, essas relações, princípios básicos pelos quais os homens se organizam societariamente, apareciam na forma de relações ideológicas como direito jurídico-formal burguês. Neste caso, uma parte do social (a classe trabalhadora), sem controle sobre os meios de produção, ficava destituída de propriedade econômica. Marx vai detectar aí, então, $a$ contradição entre as forças produtivas e as relações de produção.

Com base nessa argumentação, podemos, então, interpretar Marx. Havia, no seu tempo, uma correspondência na forma de contradição entre as forças produtivas e as relações de produção. Entretanto, mesmo estando em contradição, essa correspondência se fazia na relação com o modo de produtividade, que era consonante com a ampliação do espaço de racionalização de sua época.

O modo de aparecer da dominação social burguesa levava a indicar que a supressão das formas dogmáticas do poder-domínio se daria pelo simples acesso do produtor imediato aos meios de produção. Deste modo, o controle das forças produtivas peia classe trabalhadora requereria apenas a posse dos meios de produção por parte da classe trabalhadora, para se 
estabelecer uma nova relação entre os homens, possibilitando o surgimento de uma nova organização social.

Nos dias atuais, a força de trabalho do produtor imediato perde seu peso no processo de produtividade para a ciência e a técnica contemporânea, que passam a ocupar o lugar de principal força produtiva.

Com base nesse fato, podemos, então, reinterpretar Marx. Hoje é a força de trabalho do produtor não imediato (setor terciário), como um $a$ priori tecnológico ${ }^{3}$, que é a responsável por uma produtividade que se realiza no contexto do desenvolvimento das forças produtivas. Deste modo, a produtividade é dada por uma força de trabalho como "energia mental", cristalizada nos produtos e não passível de ser medida pelo tempo de trabalho socialmente necessário. Além do mais, essa força de trabalho que valoriza o capital não se articula mais com as relações de produção no sentido estrito, classico-marxista, ou seja, como obstáculo às forças produtivas, como elemento capaz de acirrar a contradição existente na base da economia, levando ao colapso o modo de produção e a sua organização específica.

Assim, no capitalismo contemporâneo, não há uma correspondência na forma de contradição entre as forças produtivas e as relações de produção enquanto relações de base econômica, porque o modo de produção que se coloca articulado com o espaço de racionalização não é o mesmo da época de Marx.

Contudo, a contradição persiste. Ela apenas se deslocou para o nível global do sistema. Deste modo, a contradição aparece como Razão de Estado, como um processo de salvaguarda do sistema social em risco de desintegração. Neste nível, enquanto relação de natureza política, a contradição continua gestando sua ideologia. A contradição apenas se alterou no seu modo do aparecer social ${ }^{4}$.

\footnotetext{
${ }^{3}$ A técnica é uma simples idéia na forma de conceito. Seus resultados, sim, é que são concretos e empiricamente tratáveis. Como simples idéia, ela é uma representação do mundo empirico.

${ }^{4}$ Neste ponto divergimos de Habermas, quando este afirma que as contradições entre as forças produtivas e as relações de produção não constituem mais pontos vulneráveis para o capitalismo tardio.
} 
da economia, nao leva mais a indicar que a supressão das formas dogmáticas do poder-dominio se dará pelo simples acesso do produtor $\mathrm{O}$ modo do aparecer da dominação social burguesa, não estando mais sendo legitimado pelo ocultamento da contradição existente na base imediato aos meios de produção. $\mathrm{O}$ controle político das forças produtivas pela classe trabalhadora, com base na simples socialização dos meios de produção, não é mais suficiente para possibilitar o surgimento de uma nova organização social, inaugurando novas relações entre os homens. Aliás, Marx já nos alertara sobre isso, instigando-nos à reflexão 5 .

Mas, como o processo de racionalização se efetiva por uma razão de natureza dupla, podemos dizer que no passado a força de trabalho do tipo "corporal" do produtor imediato dava a tônica da produtividade, e era essa força que valorizava o capital. Daí, se situar nela a fonte de dominação do capitalismo. Dessa fonte o sistema social retirava seu processo de legitimação. A ideologia como fator de legitimação colocavase, portanto, numa superestrutura determinada por uma infra-estrutura. A ideologia, então, aparece como falsa liberdade quando se realiza uma troca de equivalentes.

Agora, no presente, a força de trabalho do tipo "mental" dá a tônica da produtividade e é essa força que valoriza o capital. Daí se situar nela a fonte de dominação do atual capitalismo, através do qual o sistema social vai retirar seu processo de legitimação ${ }^{6}$.

\footnotetext{
${ }^{5}$ Ver Marx (1982b, p. 149). Marx alerta Proudhon dizendo que a renda e a propriedade são colocadas pelos economistas como erros, porque sao pensadas como categorias eternas. A contradição entre as forças produtivas $\mathrm{c}$ as relações de produção, não estando mais assentadas numa base econômica, perdem seu peso político como fenômeno capaz de liberar formas emancipatórias humanas, na forma de conflitos de classes economicamente antagônicas. Assim, as classes sociais nao são mais capazes de promover a emancipação humana, porque, ao perderem seu peso politico, perdem, igualmente, seu peso no processo de dominação social. $O$ alerta de Marx continua valendo. Seus "interpretadores" não devem considerar as categorias marxistas como categorias eternas.

${ }^{6}$ Nos dias de hoje. o processo de dominação social põe-se para além do Direito Natural que, desde Locke e Kant, tem seu conteúdo justificado pelas relações legitimas de produção. Para nós, o processo de legitimação ocorre da seguinte forma: quando os homens produzem, e aí está caracterizado uma forma típica de ação instrumental, o fazem tanto por uma ação de natureza instrumentalists (trabalho) quanto por uma ação comunicativa de cooperação no trabalho, sendo que esta se caracteriza por uma ação de
} 
Entretanto, a ação racional do tipo "mental" produz representações apriori do mundo empírico. Como um produto apenas da razão, em forma de representação, um a priori tecnológico, independente de seus resultados, vai tornar-se o meio de legitimação para uma nova forma de dominação social. Conseqüentemente, em virtude de ser essa força a que valoriza e legitima o capital, essa forma de legitimação não pode ser mais retirada como interpretação de um mundo que se desenvolve no interior de um processo de racionalização exclusivamente instrumental. O processo de legitimação no capitalismo contemporâneo dá-se, e de modo relevante, como interpretação de um mundo que se desenvolve no interior de um processo de racionalização de natureza simbólica.

O processo de legitimação da dominação social no capitalismo de hoje volta a assumir uma forma política imediata, sendo mediata sua forma econômica. Contudo, diferentemente das sociedades "tradicionais", anteriores a Marx, essa forma de legitimação não tem mais condição de se fazer na base da tradição cultural. Acompanhando a ampliação do espaço de racionalização dos tempos de modernidade, a técnica torna-se uma "ideologia". Como uma simples idéia ela aparece como a própria razão instrumentali sta, independente das ações humanas, sendo resultado de um sistema autodirigido. A técnica transforma-se, então, numa "ideologia" capaz de ser, ao mesmo tempo, fator de dominação e legitimação do sistema social.

caráter normativo. Logo, tem-se uma razão agindo de natureza dupla, têm-se, conseqüentemente, modos de legitimação e dominação social agindo com natureza dupla. No decorrer do tempo histórico, quando se tinha um nível de crescimento das forças produtivas, no qual se admitia o modo de produção exercido prioritariamente como ação instrumental, a ideologia manifesta-se, no plano prático da política, na forma de interesses não compensados (eu produzi, agora quero o que é meu de direito). Na contemporaneidade, na qual a ciência e a técnica tornam-se a força produtiva principal, o trabalho, prioritariamente, é dependente de habilidades cognitivas e de modos de escolhas racionais; a ideologia se manifesta na fonila de interesses não obtidos nos limites de sucesso da ação (eu produzi e só não lenho o que é meu porque fiz minha escolha mal — deforma incompetente — no contexto da "racionalidade" existente). As formas de legitimação, ocorrendo de maneiras diferentes, expressam diferentemente as formas de dominação social. No entanto, esta última forma ideológica de legitimação facilita o processo de dominação social, diminuindo as resistências ao poder estabelecido. 
Podemos, então, afirmar que, com o desenvolvimento das forças produtivas, ampliou-se de forma gigantesca o espaço de racionalização instrumental que, por sua vez, impõe aos homens a necessidade de novas interpretações do mundo. Deriva daí a exigência de novas relações entre os homens e, conseqüentemente, uma nova forma de dominação social, que ainda continua se fazendo no interior de uma organização social especificamente capitalista. Caem por terra as "antigas" formas de legitimação do domínio capitalista, tão bem caracterizadas por Marx no seu tempo. O espaço ampliado da razão instrumental, enquanto um a priori tecnológico, exige para si o papel de fator de dominação.

\section{Dominação social e emancipação humana}

O modo como se efetiva uma produtividade e sua forma de valorizar o capital promovem desenvolvimentos sociais e liberam movimentos emancipatórios. Porém, para nós, os atos de aprendizagem humana como processo de racionalização, empreendidos na relação entre homem e natureza (trabalho), demarcam os caminhos da história da humanidade, pelo controle que os homens exercem sobre a natureza. No entanto, esses atos não levam necessariamente à emancipação humana.

No passado, devido ao nível de desenvolvimento das forças produtivas, as ações humanas constituídas de "corpos racionais" de natureza técnico-operativa colocavam-se como forças propulsoras do desenvolvimento. A relevante função social exercida por essas ações indicava que um simples acesso aos meios de produção por parte de uma parcela da sociedade (a classe trabalhadora) era suficiente para demarcar o progresso da humanidade, bem como sua emancipação.

Entretanto, as contradições situadas na base da economia impediam o acesso da generalidade dos homens no fazer da sua história, manifestando-se como instrumento de dominação social. Suas características concretizavam-se pela efetivação de um domínio por 
manipulação, coerção e violência institucional, como exploração de uma força de trabalho do produtor imediato. Essas contradições liberaram movimentos emancipatórios da classe trabalhadora, os quais reivindicavam a propriedade coletiva dos meios de produção como condição necessária para o controle das forças da natureza e como ponto de partida para o surgimento de uma nova ordem social.

No presente, no determinado momento de desenvolvimento das forças produtivas, as ações humanas constituídas de "corpos racionais" de natureza técnico-mental (um a priori tecnológico) colocam-se como forças propulsoras do desenvolvimento. A relevante função social exercida por essas ações vai demarcar o progresso da humanidade. No entanto, as contradições que estavam situadas na base da economia deslocaram-se para o nível geral de dominação de um subsistema político, gestando urna nova ideologia, que se identifica com o próprio domínio. Deste modo, a ampliação do espaço de racionalização instrumental identifica-se com o próprio domínio.

Essas contradições vão alterar a natureza dos movimentos emancipatórios, que perdem seu potencial enquanto movimentos gestados por antagonismos de classe ${ }^{7}$, porque a libertação do poder-domínio não se pode dar no mesmo contexto de racionalização instrumental, no qual aquele se faz e se fortalece. Mas, por outro lado, ganham seu potencial de emancipação enquanto movimentos gestados pelas contradições incrustradas no subsistema político, no qual um apriori tecnológico tende a se tornar uma forma universal de produção material. Nessa forma de produção, a técnica passa a circunscrever toda uma cultura e dá como resultado um mundo interpretado apenas como resultados empíricos retirados de um processo de racionalização (Habermas, 1983, p.319).

\footnotetext{
${ }^{7}$ Estamos entendendo por movimento de emancipação de classe aquele que busca a posse dos meios de produção como condição necessária de acesso ao poder político, como estratégia de supressão das formas dogmáticas do poder.
} 
Hoje, a relação forças produtivas versus relações de produção configura-se numa nova constelação na qual forças produtivas e forças de trabalho movimentam-se em condições específicas de produção. Essa configuração explica-se em virtude de uma enorme ampliação do espaço de racionalização instrumental, que transformou a força de trabalho racional do tipo "mental" na principal fonte de produtividade. É essa força de trabalho que valoriza o capital. Porém, essa nova força de trabalho tem como característica situar-se em pontos diferentes no interior de um contexto do agir racional: ela valoriza e ao mesmo tempo legitima o capital. Isto só é possível porque a força de trabalho assume a forma política de um discurso técnico derivado da razão e, portanto, passível de ser estabelecido por procedimentos não referentes à experiência.

Essa força, quando mantém relações com a experiência, gera resultados concretos e torna-se fonte de produtividade. Gestações que vão organizar os meios eficazes de controle sobre as forças da natureza e que têm como referenciais de comportamento as bases técnicas como orientação da ação (agir racional instrumental).

Entretanto, quando essa força não mantém relações com a experiência, transforma-se em ações de caráter subjetivo, fatores de legitimação; gesta ações que vão interiorizar papéis sociais de obediência às normas. Essas ações têm como referenciais de comportamento máximas retiradas de um sistema de valores através dos quais os homens interagem entre si (escolha racional ou agir estratégico).

Podemos deduzir que o deslocamento do processo de valorização do capital da base econômica para o subsistema político vai modificar de forma radical o processo de legitimação. A legitimação do sistema se efetivará de forma preponderante na relação da força produtiva principal, com procedimentos relativos a máximas retiradas no interior de um sistema de valores, como ações de escolhas racionais no contexto de um agir racional estratégico.

Deriva daí que a "ideologia" da técnica, gestada na nova constelação das forças produtivas e relações de produção, não se apresenta 
mais na forma ilusoria de satisfação de interesses não compensados, devido a um agir tipicamente instrumental, mas na forma ilusória de interesses não obtidos no limite do sucesso, devido às próprias escolhas racionais como agir estratégico. Nesse caso, o processo de legitimação realiza-se como ações de natureza normativa e, portanto, dependente da vontade dos homens, ou seja, do senso da razão prática.

Os homens realizam suas atividades em relação com a natureza (ambiente), através de esforços individuais e coletivos, no contexto de um sistema social, como processos de preservação da vida. Essas atividades efetivam-se por um processo de reorganização, através da autocompreensão de indivíduos socializados, que se estrutura numa linguagem cotidiana capaz de orientá-las (Habermas, 1987, p.263). Pelo processo de individuação, os homens realizam ações visando à formação das suas estruturas de personalidades e respectivas capacidades cognitivointelectuais. E, pelo processo de socialização, realizam ações que visam à sua integração nas tarefas de trabalho, garantindo solidariedade e cooperação. Esses dois processos se articulam e produzem uma interpretação cultural acerca do mundo. Essa interpretação é que dará a forma para um processo de legitimação. Torna-se modelo de ação social, regra normativa básica de conduta de uma ordem legítima.

Entretanto, essas atividades se realizam por um processo de racionalização operativa do mundo empírico, visando à construção de objetos humanos que vão satisfazer as necessidades humanas (produção material). Dependem, portanto, de ações concretas que põem em movimento as forças produtivas. Porém, essas forças só entrarão em funcionamento através de um processo social de divisão do trabalho, no qual são alocados indivíduos de acordo com suas capacidades cognitivointelectuais. Desse modo, os processos de individuação e socialização articulam-se com o processo de societarização constituído por uma organização social de ordem legítima, que alocará os indivíduos segundo uma divisão do trabalho, visando à produção da riqueza social. 
Em vista disso, vamos concluir que as atividades humanas se efetivam como ações na relação com as forças produtivas e são condicionadas por um processo de divisão do trabalho e por uma organização social de ordem legítima. Logo, as atividades humanas realizam-se por um processo de racionalização, no qual as ações sociais assumem um sentido racional instrumental e, ao mesmo tempo, racional interpretativo do mundo empirico*.

Ora, isto só é possivel quando as atividades humanas de um mundo organizado na sua forma econômica se articular com o mundo organizado na sua forma institucional, através de valores compreendidos na forma $a$ priori de representação do mundo empirico, com base em princípios necessários e universais, como meios de conservação da vida. Nesse sentido, esses princípios assumem uma forma política que vai orientar as atividades humanas tanto do ponto de vista da produção material quanto do ponto de vista normativo de obediência a uma ordem legítima, retirada de uma interpretação cultural com um sentido prático da razão. No entanto, essa possibilidade só se torna viável através da formação da vontade política como processo de formação democrática da cultura, no qual podemos definir como vontade política aquela vontade que se transforma num desejo mediado por um valor derivado da razão, que, tomado na relação com a experiência, se constitui em princípio universal e necessário (Kant, 1991).

\footnotetext{
'Eni se aceitando a razão agindo com natureza dupla, a força de trabalho como ação de natureza instrumental é. também, de natureza dupla: é uma ação que pensa e ao mesmo tempo age no mundo. Mas, somente a força de trabalho de natureza "mental" (a que pensa e compreende o mundo, como por exemplo a técnica) é capaz de produzir representações a priori do mundo empírico. Deriva dai que o processo de racionalização, diferentemente de como Weber o pensou, é também de natureza dupla. E mental como processo de reflexão autonomizante dos indivíduos, no qual estes pensam a realidade $a$ priori e é agir instrumental quando essas formas de ação pensadas se concretizam em ações sociais. Weber, ao priorizar uma objetividade cientifica própria do pensamento da modernidade, não distinguiu momentos de autonomização e momentos de racionalização, estes sim, processos de racionalização retirados de conhecimentos a posteriori. Decorrentes de um processo de autonomização, os desejos, por serem atos de pensamento do sujeito (da mente e/ou self) que busca a satisfação de objetos desejados, orientam formas concretas de construção dos objetos na vinculação com o pensamento da razão. Os desejos tomam-se, então, orientações valorativas de caráter subjetivo, que vão dar sentido às ações concretas como momento do pensamento que dá a orientação, como sentido da razão prática. As ações produtivas como momento objetivo transformam os desejos em ações concretas realizadas pelos Iraniens. Desse modo, os desejos tornam-se sentidos através dos quais é possivel explicar a unidade dos processos das ações sociais, tomando- as compreensíveis como motivos para ações racionais que se desenvolvem
} 
Hoje, evidenciamos o surgimento de movimentos sociais constituídos de atores cuja ação se baseia numa disposição homogênea em torno dos meios de produção. Esses movimentos têm gestado idéias, experimentando novas formas de relações sociais que produzem o alargamento do espaço dos direitos, da cidadania. Eles vêm proclamando a liberdade, independente de uma sujeição jurídica ao poder estatal. Cremos que eles se aproximam do que poderíamos chamar de movimentos emancipatórios ou movimentos de natureza política, uma vez que suas estratégias se coadunam com o momento atual, possuindo um caráter universal fincado em princípios de solidariedade ${ }^{9}$. Esses movimentos parecem adiantar-se à realidade social e política. Neles impera o bom senso que os conduz à formação de reais coletividades sociais.

De fato, hoje, a mais sensata formulação de um estado de coisas nos parece ser compreendida quando constatamos o seguinte: de um lado, temos a política, enquanto ação emancipatória, presa ao aspecto dinâmico de uma estrutura estatal; de outro, temos uma estrutura estatal tentando substituir a ação emancipatória por um discurso técnico, excluindo a formação democrática da vontade política.

A experiência histórica do socialismo real, que pretendeu buscar a emancipação humana através do acesso aos meios de produção e uma economia planificada nos ajudam a esclarecer o equívoco do materialismo

tanto no contexto de um mundo do trabalho (acervo cultural técnico) quanto no contexto de um mundo interpretado através de interações comunicativas (acervo cultural simbólico). Ora, como as ações racionais concretas são de natureza dupla e se desenvolvem nas estruturas sociais, elas se manifestarão também numa forma dupla nos espaços do público e do privado. Efetiva-se, assim, o que nós estamos chamando de praxis social dupla, na qual teoria e prática não se separam. Cremos que, através desta reformulação conceitual, preservamos as idéias mais caras de Habermas e Arendt. Na verdade, a praxis assume apenas sentidos diferentes, de acordo com os objetivos que se quer alcançar (cf. Habermas, 1987, e Arendt, 1991). Para um entendimento das posições teóricas de Weber, confira Aron, 1982; Freund, 1970 e Cohn, 1989.

' Esse é o tema de nossa tese de doutorado Para uma (re)orientação ética de movimentos de natureza politica, que visa subsidiar os movimentos organizados da sociedade civil com instrumentos políticos capazes de permitir aos mesmos se (re)estruturarem nos seus modos de organização e estratégias políticas, com o fim de ampliar os espaços democráticos de atuação humana nas sociedades contemporâneas. 
histórico. O salto qualitativo da humanidade - a passagem do reino das necessidades para o reino da liberdade - como fonte de inspiraçãocontexto de um processo de racionalização instrumental próprio da relação aristotélica do materialismo histórico não se dá somente no homemnatureza, mas se efetiva também na dimensão das relações de poder como interpretação simbólica do mundo.

$\mathrm{Na}$ verdade, muitos dos movimentos reivindicatórios da sociedade civil vêm organizando suas lutas políticas no interior de um contexto de racionalização instrumentalista do mundo empírico e, dessa forma, repetem os clássicos movimentos socialistas. Entretanto, tais movimentos se fragmentam dia a dia, destruindo-se enquanto coletividades sociais.

Classes sociais são relações cuja racionalidade única não pode mais explicar a realidade dos atos exercidos pelos seus atores. A racionalidade no contexto da ação racional instrumental produz uma multiplicidade de escolhas. Essas escolhas dependem das vontades e são retiradas de cálculos individuais. Nesse sentido, os movimentos reivindicatórios não podem mais ser explicados do ponto de vista das classes sociais, mas do ponto de vista de vontades individuais que se vão refletir na posição estrutural ocupada por tais movimentos. Desta maneira, os movimentos reivindicatórios que buscam a emancipação humana devem reformular sua visão de mundo.

A reflexão acerca daquela experiência histórica indica-nos, no presente, dois caminhos a percorrer, que podem conduzir os novos movimentos emancipatórios a se libertarem do poder configurado na dinâmica de uma política estatal, que se faz por um domínio cuja legitimação se encontra na própria razão do processo de dominação: a busca de uma praxis teórico-técnica que permita aos atores a aquisição de um saber produtivo como forma de operar racionalmente as forças da natureza, busca essa que deve se fazer, simultaneamente, para a construção de uma praxis teórico-prática que permita a esses mesmos atores a aquisição de um saber crítico-reflexivo da lógica do domínio, como mecanismo de supressão da "ideologia" da técnica. 
À vista de toda a nossa argumentação, realizada nas páginas anteriores, é sensato propor a seguinte conjetura: a estratégia mais adequada de libertação das formas dogmáticas do poder, bem como da supressão de sua ideologia, dá-se pela realização de lutas políticas que se organizam nos parâmetros de um processo de formação democrática da cultura $^{10}$.

Isto nos parece razoável porque a formação democrática da vontade política no capitalismo contemporâneo é obstruída por uma ideologia que se apresenta na forma social de vontades não satisfeitas e compensadas. Deriva daí que a libertação do domínio vai dar-se através da reflexão acerca de um mundo interpretado segundo critérios práticos da razão.

\section{Educação como produção de cultura democrática}

Constatada a mudança do processo de dominação social na contemporaneidade, modifica-se, também, a função sociopolítica da educação. E sensato, portanto, propor uma reformulação conceitual das tarefas educativas, visando interpretá-las e compreendê-las de acordo com sua função social e sua contribuição para a emancipação humana. E o que faremos a seguir.

É possível reconhecermos na relação capitalismo e organização do Estado a sede de alguns conflitos que colocam este último como definidor de uma esfera do poder. Para Offe ( 1984), a raiz desses conflitos situa-se na dependência estrutural do Estado contemporâneo à acumulação capitalista. Dependente do processo de acumulação capitalista, o poder público necessariamente deve manter condições exteriores de seu poder, constituindo políticas públicas que favoreçam o processo privado de acumulação.

\footnotetext{
${ }^{10}$ Estamos entendendo por cultura o mesmo que Habermas: cultura é um armazém do saber do qual os participantes de uma comunicação extraem interpretações no momento em que se entendem mutuamente sobre algo (cf. Habermas, 1984, p. 125)
} 
Em suas análises acerca dos Estados mais desenvolvidos política e economicamente, como os da Europa, Offe afirma que o conceito de Estado capitalista pode ser expresso por uma forma institucional de poder público em relação com a produção material, caracterizando-se por quatro determinações funcionais: privatização da produção, dependência de impostos, legitimação democrática e acumulação como ponto de referência.

Estabelecendo como enfoque analítico principal a conexão entre o poder estatal e a acumulação privada, na qual a preservação do poder é dependente da acumulação, o referido autor vai concluir que as estratégias que produzem e reproduzem a compatibilidade entre aquelas quatro determinações definem o que se compreende por "política": política é apenas o aspecto dinâmico da estrutura estatal.

Decorrente dessa dependência, o Estado só encontra uma saida: criar condições para que cada indivíduo seja incluído nas relações de troca. Dessa maneira, a existência de um mercado no qual há a incorporação de todas as unidades de valor nas relações de troca toma-se o elo fundamental entre as estruturas políticas e econômicas, conferindo ao Estado sua estabilidade política.

A essa necessidade imprescindível para o exercício de poder estatal, na fase atual do desenvolvimento capitalista, Offe chama de, processo de universalização da forma-mercadoria.

Entretanto, esse processo, como fenômeno do desenvolvimento capitalista que ocorre em Estados fortemente intervencionistas, vai fazer emergir da relação capitalismo-organização estatal uma contradição estrutural que, colocada em movimento pelo subsistema político, introduz mecanismos regidos por lógicas opostas: de um lado, um processo de reprodução administrativa da forma- mercadoria, guiado pela lógica do valor de troca, gerando interesses que passam pelo marco do sistema econômico, tais como a criação de empregos, a regulação de preços e salários etc; por outro lado, o Estado introduz um processo de desmercantilização, para evitar que esses interesses sejam generalizáveis, através de mecanismos situados além da lógica da valorização do capital. 
Nesse sentido, o sistema econômico passa a utilizar força de trabalho imaginária e a apoiar-se em instituições que não admitem o modelo mercadoria. Exemplo típico é o caso da instituição escola, na qual os professores, com suas tarefas de ensino, colocam-se como elementos contraditórios no interior das relações capitalistas. Não é certo que a escola tenha por objetivo produzir mercadorias. Seu produto expressa conhecimentos e qualificações, embora contribua para melhorar a qualidade de venda de certas mercadorias; não se caracteriza como mercadoria, pois a força de trabalho é vendida por aqueles que recebem a "produção" da escola.

Os professores, portanto, enquanto categoria específica de trabalhadores, colocam-se no interior da produção capitalista como elementos contraditórios que questionam a base de legitimação do sistema. Muito embora não sejam produtores imediatos, sua atuação não deixa de ser perigosa. Erodindo as relações capitalistas de produção e questionando a base de legitimação do sisterna, suas atividades se transformam num ponto nuclear de conflito, propiciando a realização de lutas políticas destinadas a superar a forma mercadoria como princípio de organização da reprodução social.

Constatamos, nas análises acima referidas, um equívoco de Offe. Ele não conseguiu apreender o vínculo real entre forças produtivas, condições específicas de produção e processos de valorização do capital no estágio atual do desenvolvimento capitalista.

Ao centrar seu enfoque analítico no modelo da forma-mercadoria, Offe não pôde captar o deslocamento das contradições das forças produtivas e relações de produção para o nível do subsistema político, bem como a emergência de um novo processo de valorização do capital, que se efetiva na economia pelo processo de desenvolvimento tecnológico, cuja contradição se manifesta, no político, pela "ideologia" da técnica".

Offe pensa o modelo forma-mercadoria visando captar as contradições subjacentes ao modelo de Estado do Bem-Estar Social. Segundo esse modelo, o capitalismo produz e reproduz o sistema quando a base da economia assenta-se na ideologia de uma troca de equivalentes "livre" e "justa", valorizando o capital e harmonizándose com o sentido dado pelas atividades humanas. Desse modo, os imperativos contraditórios somente serão capazes de coexistir quando se esquivam com êxito à reflexão, aparecendo como algo diferente do que efetivamente sSo (cf. Offe, 1984). 
A contradição não se dá, como afirma Offe (1984), exclusivamente numa forma estrutural, obrigando o aparelho burocrático do Estado a constituir um processo de dominação política realizado por mecanismos institucionais seletivos com conteúdos de classe e que se expressam em políticas que favorecem os interesses do capital no seu conjunto ${ }^{12}$. A contradição dá-se de modo verticalizado, como um processo de maior profundidade.

O Estado capitalista, enquanto mediador político, torna-se nulo quando sua manifestação não é mais congruente com os princípios que o legitimam. Deriva daí que o aparelho estatal vai buscar um novo processo de dominação política, através de um discurso técnico no qual um apriori tecnológico configura-se como a nova ideologia. Deriva daí, também, que a estrutura estatal se torna mais vulnerável às crises motivacionais dos atores nela envolvidos.

As atividades dos professores não se situam somente como elementos contraditórios, regidos por uma lógica externa, corroendo as relações capitalistas de produção ao colocar as suas ações para além da lógica da valorização do capital. Suas atividades situam-se no interior das relações capitalistas de produção como elementos contraditórios, tendo suas ações emancipatórias presas ao aspecto dinâmico da estrutura estatal e envolvidas pelo fetiche irresistível da "ideologia" da técnica.

A ideologia, ao se apresentar como um saber a priori, que se justifica sem a necessária comprovação empírica, mata na raiz toda e qualquer reação diante de um estado de coisas, justamente por falsear a verdade na qual ela se movimenta.

\footnotetext{
${ }^{12}$ Segundo Jacobi, Offe, na sua construção teórica, formula a questão do caráter classista do Estado em termos de mecanismos que relacionam a estrutura interna do Estado e a esfera da acumulação; introduz o conceito chave de "mecanismos seletivos" para a compreensão do funcionamento da estrutura intema do Estado. O aparelho burocrático, no processo de suas atividades, possui um amplo espectro de mecanismos institucionais: a) seleção negativa - os mecanismos seletivos excluem sistematicamente da atividade estatal os interesses anticapitalistas; b) seleção positiva - a partir do espectro de alternativas restantes, o Estado seleciona as políticas que favorecem os interesses do capital, em detrimento de grupos locais e específicos capitalistas; c) mascaramento - as instituições públicas buscam manter as aparências de neutralidade de classe, mas, ao mesmo tempo, marginalizam as alternativas anticapitalistas. Esta rede intrincada de fios burocráticos permite ao Estado organizar a hegemonia capitalista sem ser controlado por ela (cf. Jacobi, 1989).
} 
Daí que o fenômeno da educação só terá sua força transformadora questionando a base ético-normativa da sociedade capitalista, quando as ações emancipatórias dos professores puderem libertar-se da coerção de uma política estatal traduzida por um discurso técnico dissimulado por uma ideologia que vai obstruir a formação das vontades políticas dos atores envolvidos no processo de educação.

Está aí, portanto, o que podemos chamar de educação transformadora e libertária. Educação libertária é toda aquela que produz, veicula, individualiza e socializa conhecimentos, na forma de representações do mundo empírico, como estratégia política de libertação das formas dogmáticas do poder, bem como da supressão de sua ideologia.

A educação libertária colabora na realização de lutas políticas que se organizam nos parâmetros de um processo de formação democrática da cultura. Esse é o papel relevante exercido pela educação no atual estágio de desenvolvimento capitalista, que caracteriza a cultura como princípio educativo.

E verdade que, nesses últimos anos, o tema educação tem sido analisado do ponto de vista das classes sociais como medium de ações emancipatórias da classe trabalhadora. Entretanto, nos dias de hoje, as lutas políticas dos trabalhadores têm sido abafadas por uma ação política do Estado, que destrói as formas emancipatórias nas quais Marx acreditara.

Agora, estas lutas emancipatórias deslocam-se para a periferia do sistema, e é aí que elas devem ser retomadas como ações emancipatórias vitais. Para nós, é neste ponto que se dá a passagem do trabalho como princípio educativo para a cultura como princípio educativo deformação democrática.

As ações emancipatórias são hoje obstruídas por soluções técnicas (discurso técnico); logo, sua superação pode dar-se por um processo de elucidação pedagógica, como instrumento eficaz Aformação democrática 
da cultura por um processo de desideologização no qual desideologizarse significa tornar-se consciente dos sistemas e processos sociais ${ }^{13}$.

Nesse contexto, a educação, produzindo interpretações a priori da realidade, pode explicar o elemento central dos significados das normas e da obrigatoriedade de obedecê-las, quando estas são intersubjetivamente reconhecidas por todos. Produzindo essas interpretações na vinculação com a razão prática, o processo educativo conduz à formação de vontades coletivas que se formam com base em princípios universais das necessidades. Assim, a educação torna-se um instrumento eficaz de decisão coletiva racional, principio formador da vontade política.

É, portanto, no interior de um processo de formação das vontades individuais, que se formam pedagogicamente como vontades coletivas, que se vai localizar o fenômeno da educação como instrumento de formação democrática da vontade política. Tal educação se dá quando os princípios necessários e universais assumem uma forma política que vai orientar as atividades educativas tanto do ponto de vista da produção material (pela aquisição de um conhecimento teórico-técnico) quanto do ponto de vista normativo de obediência a uma ordem legítima, retirada

\footnotetext{
${ }^{13}$ Habermas foi quem nos instigou a pensar o conceito de desideologização, uma inovação conceitual que introduzimos, com o fim de captar o fenômeno de mediação política da educação no capitalismo contemporâneo. O conceito de desideologização, para nós, é um conceito-chave, pois se põe como elemento heurístico do método analítico-descritivo que estamos adotando no nosso trabalho de tese de doutorado. Ele permite, sem abandonar as exigências de rigor científico, o resgate da subjetividade humana presente nas práticas políticas. Habermas, em suas páginas, desenvolve a proposta de um tratamento crítico-elucidativo das "neuroses sociais", tendo como modelo analítico a psicanálise. Reformulado por nós, esse tratamento pode ser resumido e complementado no que se segue: as representações imediatas como produto de uma consciência falsamente motivada e, portanto, ideologizada, destacam-se na linguagem cotidiana como perturbações de interações sociais, provocando distorções do pensamento derivadas de uma análise errática da realidade social. Essa consciência forma posturas comportamentais constantes e inalteradas, imunes à crítica, legitimando uma ordem estabelecida. No entanto, essa postura, quando tratada de forma crítica, produzirá, em situações de diálogo, novas interpretações do mundo vital que, postas na relação com a realidade social, transformam-se em modelos de ação social, por serem análises reais e produtos de uma consciência real. Está posto ai o papel da educação como mediação política no capitalismo contemporâneo. Um papel que se efetiva pedagogicamente por um discurso crítico, cujo fim é o de eliminar, por ato de reflexão, as vontades que nascem das contradições da realidade, revelando o lado oculto da ideologia (cf. Habermas, 1987, p.288-312).
} 
de uma interpretação cultural com um sentido prático da razão (pela aquisição de um conhecimento teórico-prática).

A educação como fator de mediação política é um processo de autocompreensão de indivíduos socializados que se estrutura numa linguagem cotidiana capaz de orientar de forma prática as atividades pedagógicas através de um processo de formação discursiva da vontade. Deriva daí que sua principal tarefa pedagógica se realiza como aprimoramento de um processo de individuação no qual os indivíduos estruturam suas personalidades e adquirem conhecimentos cognitivointelectuais, com fins de, segundo o senso da razão prática, interpretar e operar de forma conseqüente, na relação com os outros, o seu mundo. E nessa intersecção entre processo de individuação e socialização que reside o real vínculo entre educação e estrutura socioeconômica capitalista.

Nesse contexto, em nível da reflexão como prática críticoeducativa, os agentes individuais que desenvolvem ações sociais no terreno das estruturas sociais são levados a tematizar as contradições da sociedade capitalista, produzindo-se como reais sujeitos do processo político. Assim, tornam-se capazes de desenvolver ações coletivas, tornando-se eficientes articuladores de demandas através de decisões políticas racionais.

Se aceitarmos como válido, do ponto de vista analítico, o conceito de natureza dupla da força de trabalho, o fenômeno da educação é singular. Fornece conhecimentos e qualificações, tendo como característica fundamental a tarefa de conduzir pessoas a produzir juízos sintéticos a priori da realidade, e dá, também, às pessoas a aquisição de habilidades técnicas para tarefas de natureza instrumental. A educação torna-se, assim, um excelente meio de preparação da força de trabalho.

Entretanto, o ato da educação realizado através de uma razão de natureza dupla - como discurso teòrico-pràtico e como discurso teòricotecnico - transforma o fenômeno da educação em um eficaz meio de produção, haja vista que não podemos entender as forças produtivas a não ser como resultado de ações humanas. 
Porém, as forças produtivas dependem, para funcionar, de um processo social de divisão do trabalho no qual os homens se colocam de acordo com suas capacidades cognitivo-intelectuais. Desse modo, o processo de individuação e socialização articula-se com o processo de socieíarização, responsável pela distribuição da riqueza social produzida e pela alocação dos homens segundo a divisão do trabalho. Mas, como as forças produtivas só funcionam por intermédio de ações humanas que lhes vão dar sentido, vale dizer que o movimento das forças produtivas só entrarão em funcionamento quando os atos de desejos assumirem a forma de valores que vão dar sentido prático às forças produtivas, as quais se realizam como atos concretos $*^{4}$.

Os desejos, então, tornam-se orientações valorativas de caráter subjetivo, dando sentido às ações concretas que se realizam através das forças produtivas, tornando compreensíveis as ações sociais desenvolvidas no terreno das estruturas sociais. Mas, como as ações sociais racionais concretas configuradas numa força de trabalho são de natureza dupla,elas se manifestarão também como praxis social dupla nos espaços do público e do privado.

Deriva daí que o ato de educar consiste na transformação dos desejos em atos concretos, caracterizando, essencialmente, o fenômeno

\footnotetext{
${ }^{14}$ Todas as vezes que desejamos alguma coisa, essa coisa é para alguém um valor que vale a pena satisfazer. Dai nasce uma vontade. A vontade pode ser definida, então, como uma relação entre o sujeito e o objeto, derivada da relação homem-natureza, na qual o homem tenta preservar-se na contingência dessa relação. Entretanto, vamos evidenciar um vinculo dialético entre vontade e desejo. A vontade nasce do desejo, mas só é transformada em desejo quando mediada por um valor. Assim, os desejos tomam a forna de um valor de objeto de satisfação. Vamos deduzir daí que na relação homem-natureza, mediada pelo trabalho, nascem as vontades que, transformadas em desejos, tomam a forma de um objeto de satisfação. Mas os homens só vão entender um objeto de satisfação como valor na relação desse objeto com a realidade empírica, ou seja, como mundo sensível dos fenômenos. Logo, os valores tomam a forma de entendimentos da razão como representações a priori do mundo empirico. São, pois, os valores formas de pensamento, conceitos, princípios constitutivos do entendimento que se baseiam em juízos necessários e universais, cuja necessidade e universalidade só é dada pela experiência. Por isso, quando se tem uma vontade que se transforma num desejo e um desejo proveniente de uma vontade que nasce das contradições da realidade, temos uma vontade mediada por um valor que não guarda relação com o mundo sensível dos fenômenos. Temos, então, uma ideologia, uma distorção do pensamento, enfim, uma ficção (cf. Kant, 1991).
} 
da educação como um processo de racionalização, no qual as ações sociais assumem um sentido racional instrumental do mundo empírico, próprio de um mundo organizado na sua forma econômica e, ao mesmo tempo, um sentido racional interpretativo-simbólico do mundo, próprio de um mundo organizado na sua forma de um viver sociocultural. Com isso, produz a educação a ampliação de um espaço democrático de atividades humanas livre de toda e qualquer forma de domínio.

\section{Educação e desideologização}

A educação pensada como princípio formador da vontade política leva-nos a sugerir três proposições: a) a educação produz pessoas empenhadas na tematização das contradições da sociedade capitalista; b) produz como conseqüência pessoas eficientes na articulação de demandas, sendo capazes de tomar decisões políticas; c) produz pessoas capazes de adotar ações coletivas homogêneas com base em princípios de reciprocidade, solidariedade e justiça.

Essa última proposição nos interessa de modo especial, pois, sendo a ação política de natureza coletiva, pessoas com essa capacidade produzem uma identidade coletiva, provocando o aumento da força política do grupo social a que pertencem.

As sentenças acima expostas nos levam a verificar que existem contidas nelas três correlações possíveis quanto à busca de satisfação dos desejos e adoção de posturas comportamentais, a) as pessoas adotam posturas comportamentais de acordo com as vontades individuais; b) adotam posturas comportamentais de acordo com as vontades do grupo a que pertencem; c) adotam posturas comportamentais de acordo com princípios de necessidades universais. No primeiro caso, configuram-se pessoas cujos interesses se individualizam; no segundo, pessoas cujos interesses se corporativizam e, no terceiro caso, pessoas cujos interesses 
se generalizam de acordo com princípios ético-morais. Neste terceiro caso, encontra-se a questão nuclear da nossa hipótese.

A educação pode mediar a formação de pessoas cujos interesses se generalizam, produzindo indivíduos capazes de interpretar o mundo em conformidade com uma certa noção de interesses e destino comuns, com uma certa "semelhança" produzida através de um processo discursivo da vontade política. E neste processo que se efetivará a transformação dos desejos em atos concretos mediados por valores universais^.

Mas os indivíduos só transformam os seus desejos em atos concretos quando põem em movimento as forças produtivas. Deste modo, os desejos vão realizar-se como construção de objetos de satisfação (produção econômica) nos contextos de um processo de individuação e socialização que se articulam com um processo de societarização, estruturado em normas obrigatórias legitimadas por uma ordem estabelecida, responsável pela alocação dos indivíduos segundo uma divisão social do trabalho e por uma distribuição da riqueza social produzida.

Logo, esses processos são dependentes de um grau de disponibilidade técnica que os homens possuem acerca da natureza e de uma certa disposição (dependente de suas vontades) para realizar ações solidárias e cooperativas no trabalho. Enfim, são processos que dependem de conhecimentos e qualificações de natureza operativa e interpretativa do mundo empírico.

\footnotetext{
${ }^{15}$ No processo de formação de ações coletivas, a questão fundamental está em saber quais os tipos de mudanças estruturais, percepções e incertezas específicas que tomam racional, para várias categorias, adotar para si perspectivas conflitantes e agir com hase nelas. Assim, os atores que interagem normativamente não o fazem devido às suas capacidades de maximizar a utilidade. Interagem por uma disposição interna, com hase numa relação de confiança, simpatia e justiça que sentiram existir em si e em outras pessoas. A variável sociológica que aí se põe é a configuração de uma certa noção de interesses e destinos comuns, uma "semelhança" produzida por uma concepção vinculatória de identidade coletiva duradoura, a partir da qual os atores empreendem cálculos racionais de utilidades individuais, agindo na base da confiança. Nesse limiar, os agentes deslocamse de um paradigma econômico de escolha de contingência para um paradigma sociológico de obrigatoriedade de ordens normativas (cf. Offe, 1984, p.301). Porém, em nosso modelo de análise, o processo educativo de fomiação da vontade política vai permitir que esse deslocamento se faça ao longo de um eixo de ordens normativas de caráter universal.
} 
Nesse sentido, as atividades humanas tratadas educativamente por um processo discursivo da vontade política tornam-se um meio prático indispensável, não só para o processo de produção material (econômica), mas, também, para uma interpretação simbólica das necessidades humanas e dos modos democráticos de satisfazê-las.

$\mathrm{Na}$ produção econômica contingente das necessidades humanas, podemos evidenciar duas correlações causais de natureza conflituosa: a) uma correlação de natureza econômica na qual a razão técnica põe-se como mediadora entre os processos de individuação e socialização, em que os indivíduos agem sob os imperativos categóricos dos desejos como impulsos de autoconservação, produzindo (economicamente) a realização dos desejos, que são garantidos pelos esforços coletivos de indivíduos socializados; b) uma correlação de natureza política na qual através da razão prática os homens julgam suas necessidades e contingências, promovendo a construção de uma organização social na sua forma política. Essa correlação se dá na articulação do processo de socialização e societarização.

A primeira correlação é definida por condições de trabalho, penúria e carência de bens produzidos (Habermas, 1987). Configura-se como um conflito que vai levar as pessoas a adotar posturas comportamentais (estratégias) que visam maximizar as utilidades individuais. Nesse caso, o critério interativo-estratégico dá-se pela adoção de conviç̧ões segundo interesses individuais.

A segunda correlação é definida pela alocação dos indivíduos segundo uma divisão social do trabalho e por uma distribuição, na sua forma politica, da riqueza social produzida segundo custos e recompensas sociais. Configura-se como um conflito que vai levar estrategicamente as pessoas a adotar comportamentos que visam maximizar utilidades segundo posições ocupadas nas estruturas sociais (classes sociais). Neste caso, o critério interativo-estratégico dá-se pela adoção de convicções segundo interesses de grupos corporativos.

Nesse contexto, o determinante que guiará as ações sociais de natureza contingencial depende da forma como as pessoas interpretam 
sua realidade social e política. Ai o fenómeno da educação encontra seu papel de mediador.

$\mathrm{Na}$ sua especificidade de produzir representações apriori do mundo empirico, a educação põe-se como elemento intermediário (medium) que vai orientar as atividades humanas de acordo com o senso prático da razão, orientando as ações sociais de acordo com princípios necessários e universais.

Podemos, então, definir o fenômeno da educação como um processo de construção de identidade coletiva através do qual os homens buscam, na sua forma econômica e política, modos de organização social. Para nós, essa mediação política da educação realiza-se concretamente por um processo de desideologização ${ }^{16}$.

A construção da identidade coletiva mediada por um processo educativo de desideologização torna-se um meio pràtico-politico relevante para o resgate da subjetividade humana, possibilitando o resgate da ética na política, mesmo no contexto de uma sociedade de desiguais econômicos, na qual os atores sociais posicionam-se estruturalmente em classes sociais. A esse processo, que se dá na intersecção de produção de contingências e de necessidades humanas de natureza hipotética, chamamos de produção democrática da cultura.

As pessoas transformam seus desejos em ações humanas na junção com as forças produtivas através de meios ou instrumentos com os quais

\footnotetext{
'* Todas as vêzes que os homens fazem o uso da razão, fazem-no por uma necessidade que o precede. Produzse, então, uma interferência, que é produto da razão na produção do conhecimento. As interferências podem ser do tipo categórica, hipotética e disjuntiva. A primeira tem a ver com o primeiro contato que o sujeito realiza sobre o objeto captado pelos sentidos, conceituando-o e categorizando-o e obtendo uma representação imediata da realidade (no nosso trabalho essa representação imediata produz uma falsa consciência motivada por falsas vontades). A segunda tem a ver com o sujeito que conceitua e categoriza o objeto e emite juízos sobre ele, ditando-lhe seus predicados de acordo com a regra maior já indicada na primeira. A terceira tem a ver com a separação que o sujeito realiza, através da razão, utilizando um termo intermediário que se faz representar pelo medium ou mediação, cuja razão atua como elemento de relação, indicando a natureza que vai categorizar e conceituar o objeto. Assim, através da crítica das representações, os homens produzem o elemento intermediário entre a realidade social existente e o conceito que dela se tem. Nesse caso, a desideologização realizada por uma mediação educativa toma-se o elemento medium que permitirá a orientação das atividades humanas segundo necessidades universais (cf. Kant, 1992, p. 135-154).
} 
os homens operam e transformam a realidade. Mas a razão pensa, e a realidade existe e é transformada pela ação. A razão e sua capacidade de criar instrumentos que operam a realidade produzem a transformação da realidade, que não é, de modo algum, independente da razão. Nessa correlação, dá-se a unidade do sujeito (portador da razão) e do objeto como movimento do pensamento realizado pela consciência.

Mas, como a consciência pode formar-se na constelação razão/ forças produtivas? Forma-se quando a atuação das forças produtivas transformam a realidade segundo as necessidades humanas. Essa transformação realiza-se de modo cientificamente organizado em sua forma empírica de comprovação de fatos, concomitantemente com o modo interpretativo racional simbólico, através de valores.

Quando a satisfação das necessidades humanas ocorre através da comprovação de fatos, a razão realiza um movimento do pensamento que é resultado do processo cognitivo, mas, quando essa satisfação se dá na forma de valores, a razão realiza um movimento do pensamento de acordo com as necessidades práticas ou derivadas de um senso prático da razão, produzindo o que se pode chamar de consciência das necessidades. A consciência das necessidades pode ser verdadeira ou falsa, segundo os resultados das ações humanas que vão satisfazer ou não essas necessidades.

Não podemos, assim, pensar as forças produtivas como elementos que agem independentemente da razão, pois o conceito de forças produtivas inclue tanto os atos de desejos quanto a forma concreta de alcançar a satisfação dos desejos.

Ora, no contexto de ações políticas concretas de caráter normativo do tipo reivindicação de melhor salário, melhores condições de saúde, educação, moradia etc, as ações serão concretizadas quando a mente, como momento das forças produtivas, realizar um movimento produzindo uma interpretação apriori do mundo empírico, permitindo uma tomada de decisão política racional. 
Entretanto, essa decisão pode caracterizar-se como uma decisão de caráter de classe ou de caráter geral, de acordo com as necessidades humanas. É nesse sentido que as ações educacionais tornam-se fatores de decisão política racional; constituem-se em momento das forças produtivas que criam representações a priori do mundo empírico.

Está aí configurado o mecanismo concreto do processo de desideologização, o qual se realiza por movimentos da razão que buscam a satisfação dos objetos desejados. Através de interpretações apriori da realidade na vinculação com a razão — princípios de causalidade - , o ato educativo explica o significado central das normas e sua obrigatoriedade ou não de obedecê-las \{momento interpretativo-simbólico da razão). Além disso, através de seus elementos constitutivos do entendimento,princípios de finalidade, o ato educativo conduz à formação das vontades coletivas que produzirão ações sociais encarnadas nas estruturas sociais, com base em critérios de universalização das necessidades (momento empírico da razão).

Desse modo, a educação produz pessoas desideologizadas e eficientes nas suas decisões políticas coletivas, através do conhecimento crítico da realidade percebida, que se faz pela estruturação da linguagem acerca do que percebem e entendem.

A educação como processo de desideologização produz, coletivamente, o consenso por comunicação acerca da realidade percebida e entendida. Produz, enfim, convicções comuns ou vontade comum. Está aí, portanto, definido o que estamos chamando de educação como instrumento deformação democrática da vontade política. Está posta, então, a configuração de um modelo analítico conceitual como método de análise da realidade social e política, no qual a educação é o elemento mediano que vai permitir o resgate da subjetividade humana presente nas práticas políticas.

A estruturação desse modelo conceitual ficaria incompleta se não pensarmos em testes empíricos que possam comprovar cientificamente a 
validade do aparato conceitual que expomos neste artigo. Desafios existem e podemos mencioná-los: como os desejos transformam-se em atos políticos concretos? E possível a construção de um modelo analítico nos moldes de um rigor científico que demonstre, empiricamente, como os desejos podem tornar-se orientações valorativas na vinculação do senso-prático da razão com as atividades humanas que põem em movimento as forças produtivas? Essas são questões importantes que estão sendo objetos de reflexão. A pesquisa de nossa tese de doutorado tem se estruturado nesse sentido.

Podemos dizer que a educação, como mediação política no capitalismo contemporâneo, cumpre um papel de relevância democrática como elemento de transformação social. Ela propicia às pessoas a apropriação de um saber-cultura ${ }^{17}$. De posse deste saber, os homens vão satisfazer seus desejos de acordo com suas vontades, que motivarão as ações individuais a se tornarem relações sociais, traduzidas em ações sociais manifestadas no terreno das estruturas sociais.

A mediação política exercida pelo fenômeno da educação possibilita aos participantes dos movimentos sociais desenvolverem — via diálogo comunicacional - ações comuns. Isto implica que é no ponto de intersecção entre atores sociais e classes sociais que se efetivará a mediação educacional, formando reais sujeitos do processo da política, através de um processo de formação democrática da cultura.

Enfim, a educação como principio formador da vontade política torna-se mediadora de movimentos políticos, produzindo pessoas críticas e, por isso, empenhadas na tematização dos imperativos contraditórios de realização dos interesses de classe, bem como na supressão das formas ideológicas de legitimação da sociedade capitalista.

\footnotetext{
${ }^{17}$ Estamos aqui entendendo por saber-cultura a posse de um saber que se produz na intersecção de uma raz3o instrumentalista, desideologizada, com a razão interpretalivo-simbólica. Constitui-se, então, o saber-cultura em um armazém de conhecimentos obtidos por uma comunicação por consenso, como conhecimentos intersubjetivamente compartilhados, acerca das experiências do viver sociocultural. Deste modo, estamos complementarizando o conceito de cultura dado por Habermas (cf. Habermas, 1987).
} 
E na singularidade do ofício da educação, vinculado à produção de conhecimentos e qualificações, que o trabalho educacional vai exercer um papel preponderante na construção de uma visão de mundo superadora das formas dogmáticas do poder e de suas ideologias. Como formadora de uma visão de mundo, a educação pode introduzir elementos de discussão pública, politizando os espaços do cotidiano e formando, assim, pessoas capazes de adotar ações coletivas homogêneas, com base em princípios de reciprocidade, solidariedade e justiça, de acordo com padrões consensuais ético e morais, interpretadores do mundo de um viver sociocultural. Enfim, como formadora de uma visão de mundo interpretado culturalmente, a educação torna-se precondição de democracia na defesa dos direitos e da cidadania, pela exigência de instituições justas na distribuição de custos e compensações sociais.

No modelo analítico conceitual que expomos, a educação como desideologizadora das vontades humanas coloca-se metodologicamente como elemento heurístico. Cremos ser esta a novidade trazida pelo modelo que se propõe a um resgate da subjetividade humana. Por isso, é um modelo que leva em conta a real consistência da subjetividade humana como processo de emancipação.

Esse papel de elemento heurístico exercido pelo fenômeno da educação torna-se possível porque no método está contido a possibilidade de as forças criativas das atividades humanas prosseguirem seu caminho na busca de uma sociedade que, cada vez mais, representa o próprio homem no comando e no controle das forças produtivas. Enfim, um método que torna os homens reais produtores de sua história.

Esse método pode ser resumido nos seguintes pontos: a) as classes sociais são relações cuja racionalidade única não pode mais explicar a realidade dos atos exercidos pelos seus atores, pois as escolhas são múltiplas e dependem de escolhas individuais; b) a educação enquanto ato concreto de um discurso de elucidação pedagógica pode revelar o lado oculto da ideologia (consciência falsamente motivada) porque esse 
discurso mostra a realidade oculta e a transforma numa realidade percebida, de tal modo que o discurso se torna alo de desejo e se realiza; c) a passagem da falsa consciência à consciência real realiza-se quando o desejo se efetiva como ato concreto.

Pelas razões expostas neste trabalho, nos opomos a muitas propostas teóricas que buscam o tratamento da educação caracterizando o fenômeno educacional como um processo de estruturação de ideologias (ou contra-ideologias). Neste sentido, a educação coloca-se como contraponto à estruturação de uma ideologia dominante, dando ao fenômeno da educação um conteúdo de classe.

Tais propostas, a nosso ver, são inadequadas por não demonstrarem o caráter classista das ações educacionais, limitando-se a analisar as relações externas que dão ao processo de educação um conteúdo de classe. Assim, as ideologias só são percebidas post festum como praxis de lutas de classe, ou seja, quando já foram identificados os conflitos nos quais as opções normativas transformam-se em violência empírica. Nesse caso, as ideologias só são percebidas numa forma dedutiva e pelos resultados posteriores $^{18}$.

Enfim, aquelas propostas teóricas são incapazes de demonstrar a necessidade estrutural do fenômeno de domínio de classe, por não esclarecerem de forma conclusiva como é que a ideologia se transforma em conteúdos concretos da ação política.

A análise que expomos abre caminho para a superação daquelas teorias e de seus tratamentos metodológicos, quando colocamos as

\footnotetext{
" Para One, somente a praxis das lutas de classes realiza a aspiração ao conhecimento, e somente quando os conflitos transformam-se em violência empírica. Deste modo, ele não admite a possibilidade de comprovação empírica do caráter classista do Estado. Para ele, as afirmações teóricas acerca da dominação estatal não podem ser obtidas imanentemente à teoria, mas somente através da praxis numa forma post festum. Isto implica que os autores que fizeram um tratamento da educação na linha que estamos criticando, e essa linha foi a tônica das análises realizadas na década de 80, o fizeram segundo o arcabouço teleológico do marxismo clássico. Suas análises, apesar dos discursos em contrário, tinham um certo tom funcionalista. É necessário que as pesquisas de cunho marxista avancem para além das "deduções" ou das "avaliações" vinculadas a situações concretas (cf. Offe, 1984, p. 122).
} 
atividades dos professores situadas no interior das relações capitalistas de produção, tendo suas ações emancipatórias presas ao aspecto dinâmico da estrutura estatal. Somente assim podemos pensar sobre um processo pedagógico-crítico realizado como processo de formação discursiva da vontade política e, deste modo, identificar as ideologias que envolvem as atividades profissionais dos professores, compreendendo-as e destruindoas através de um processo de desideologização. Assim, são apreendidos não só a necessidade estrutural do fenômeno de domínio da estrutura estatal, bem como a possibilidade de os atores se libertarem desta dominação.

Concordamos que a medida de um conjunto de significados com pretensão de validez, exigência de rigor científico que se põe como validação do processo de desideologização, é de dificil comprovação empírica. Contudo, nada impede que uma orientação apriori das atividades humanas possa ser validada por testes empíricos indiretos. Desta maneira, estaria sendo demonstrada de forma conclusiva como as ideologias se transformam em conteúdos concretos da ação política. Isto é o que até agora as ciências positivistas não têm privilegiado nos seus métodos.

Nesta última década, vários autores brasileiros analisaram e (re)analisaram o tema educação numa rota de exames e (re)exames das relações entre educação e estrutura econômico-social capitalista.

Boa parte dessas análises converge para três pontos comuns: a) apreendem a conexão entre forças produtivas e relações de produção segundo um modelo dualista de classes sociais que, fincado numa "base", desenham toda a estrutura da sociedade; b) os conteúdos das obras deixam o vestígio de uma idéia central, muitas vezes colocada subliminarmente, de que a educação emancipadora do homem passa por uma estruturação ideológica que se contrapõe à ideologia dominante; c) fica também implícito nos seus conteúdos uma idéia utópica, a de que a educação, como uma atividade crítica da ideologia dominante, prepara as bases para uma futura sociedade socialista, na qual os ideais igualitários se concretizarão. 
Desse modo, a educação é focalizada e compreendida como superestrutura e, enquanto tal, é analisada na sua vinculação (relações recíprocas) com a infra-estrutura, e seu papel político é compreendido como o de formação de ideologias (ou contra-ideologias) assimiladas e produzidas pela classe proletária.

Pelas razões expostas neste ensaio, entendemos que as análises daqueles autores estão desatualizadas e perdem seu domínio de aplicação por não captarem o real vínculo existente entre a educação e a estrutura socioeconômica capitalista contemporânea.

\section{Conclusão}

A educação, como processo de desideologização das vontades humanas, pode ser uma das alternativas capazes de conduzir as pessoas a adotarem decisões políticas racionais, mesmo quando os interesses sociais estão em jogo.

Ao compreendermos a realidade contraditória, conflituosa, como uma realidade que se forma como resultado de vontades humanas, abrimos a possibilidade de construção de mecanismos concretos capazes de desideologizar as vontades humanas (e esta é apenas uma hipótese) através de um processo educativo-pedagógico, ampliando-se, assim, os espaços democráticos de uma sociedade cruelmente dominadora, violenta, como o é a sociedade do nosso tempo.

Julgamos que a ação política pode ser pensada pela noção de verdade como ação comunicativo-simbólica. A ação política assim pensada transforma radicalmente a noção de poder. Este não é mais entendido como a capacidade de influenciar pessoas e de induzi-las a um comportamento contra suas vontades, mas visto como capacidade argumentativa racional das pessoas que se envolvem em relações hierárquicas, nas quais as relações humanas se realizam em conformidade com as vontades e segundo princípios ético-morais. 
As sociedades atuais nas quais a violência muitas vezes é institucionalizada nos instiga à elaboração de um conceito de poder que possa, do ponto de vista prático da política, conduzir as pessoas a estabelecer uma convivência ético-moral humana, no contexto de um conjunto de normatização das relações sociais, fincando bases legítimas de governo, nas quais tais formas são aceitas por todos, porque são intersubjetivamente compartilhadas de acordo com o senso prático da razão.

Para nós, a praxis política concreta, enquanto praxis do discurso, é dada quando se pensa o mundo e a forma adequada de nele agir, transformando a realidade. Assim, a atividade política no espaço público vai realizar-se não como atividade política de eficiência, mas, sim, como atividade que ocorre de acordo com as necessidades de emancipação humana.

\section{Referências bibliográficas}

ARENDT, Hannah. A condição humana. Rio de Janeiro: Forense Universitária, 1991.

Entre o passado e o futuro. São Paulo: Perspectiva, 1972.

As origens do totalitarismo. São Paulo: Companhia das

Letras, 1990.

ARON, Raymond. As etapas do pensamento sociológico. São Paulo: Martins Fontes; Brasília: UnB, 1982.

BOBBIO, Noberto./Í teoria das formas de governo. 4.ed. Brasília: UnB, 1985.

CARNOY, Martin. Estado e teoria política. 2ed. Campinas: Papirus, 1988.

CHAUI, Marilena. Público, privado, despotismo. In: NOVAES, Adauto (Org). Ėtica. São Paulo: Companhia de Letras, 1994. p.345-390. 
CUNHA, Reinaldo M. Formação política e construção de identidade coletiva. In: B. Jr. Raimundo (Org.). Movimentos sociais nos anos 90. Teresina: Cepac, 1993. p.95-126.

Política e racionalidade. In: SANTOS, Raimundo, CUNHA, Reinaldo, COSTA, Luis Flavio C. (Orgs). Contemporaneidade e politica. Rio de Janeiro: Sociedade do Livro, 1994a. p.43-66.

CUNHA, Reginaldo. Para uma (reorientação ética de movimentos de natureza politica. Fortaleza: UFC, 1994b. mimeo.

ELSTER, John. Marxismo, funcionalismo e teoria dos jogos. Revista Lua Nova, São Paulo, n. 17, jun. 1989.

ENGELS, Friedrich. A origem da família, da propriedade privada e do Estado. 5.ed. Rio de Janeiro: Global, 1984 (Coleção Bases).

FREITAG, Bárbara. Itinerários de Antígona - a questão da moralidade. Campinas: Papirus, 1992.

FREUND Julien. Sociologia de Max Weber. Rio de Janeiro: Forense, 1970.

GARAUDY, Roger. Para conhecer o pensamento de Hegel. Porto Alegre: LP\&M, 1983.

GONZALES, Francisco. Razão e política. Revista Lua Nova. São Paulo, n.19, p.81-86,nov. 1989.

HABERMAS, Jurgen. A crise de legitimação no capitalismo tardio. Rio de Janeiro: Tempo Brasileiro, 1980.

Conhecimento e interesse. Rio de Janeiro: Guanabara, 1987. 
HABERMAS, Jurgen. Tècnica e ciência enquanto "ideologia". W. Benjamim, Horkheimer, Adorno e Habermas - textos escolhidos. São Paulo: Abril Cultural, 1983. (Os Pensadores)

O discurso filosófico da modernidade. Lisboa:

Publicações Dom Quixote, 1990.

. Para a reconstrução do materialismo histórico. 2.ed.

São Paulo: Brasiliense, 1990.

HAGUETTE, Tereza. Metodologias qualitativas na sociologia. Petrópolis: Vozes, 1989.

HOBBES, Thomas. De cive - elementos filosóficos a respeito do cidadão. Petrópolis: Vozes, 1993.

JABOBI, Pedro. Movimentos sociais e políticas públicas. São Paulo: Cortez, 1989.

KANT, Imannuel. Crítica da razão pura. 4.ed. São Paulo: Nova Cultural, 1991. (Os Pensadores)

LEFEBVRE, Henri. Sociologia de Marx. Rio de Janeiro: Forense Universitária, 1979.

LOWI, Michael. Ideologias e ciência social. São Paulo: Cortez, 1985.

Lógica. Rio de Janeiro: Tempo Brasileiro, 1992.

MAQUIAVEL, Niccoló. O príncipe. São Paulo: Cultrix, 1992.

MARX, Karl. Manuscritos econômicos e filosóficos. São Paulo: Abril Cultural, 1978. (Os Pensadores). 
MARX, Karl. O Capital. 7ed., São Paulo: Difel, 1982. v.1

A miséria da filosofia. São Paulo: Ciências Humanas, 1982.

MARX K., ENGELS F. A ideologia Alemã - capítulo I seguido das Teses sobre Feuerbach. Lisboa, 1981.

Obras escolhidas. Rio de Janeiro: Ed. Vitória, 1961.

NAPOLEONI, Cláudio. Lições sobre o capítulo VI (inédito) de Marx. SãoPaulo: Ciências Humanas, 1981.

OFFE, Claus. Problemas estruturais do Estado Capitalista. Rio de Janeiro: Tempo Brasileiro, 1984.

PASCAL, George. O pensamento de Kant. Petrópolis: Vozes, 1983.

Capitalismo desorganizado. SãoPaulo: Brasiliense, 1989.

Sistema educacional, sistema ocupacional e política da educação: contribuição à determinação das funções sociais do sistema educacional. Educação \& Sociedade, São Paulo, n.35, p.9-57, abr. 1990.

REIS, Fábio W. Mudança, racionalidade e política: problemas básicos de teoria e método na ciência sócio-política contemporânea. In: LAMOUNIER, Bolivar (Org). A ciência política nos anos oitenta. Brasília: UnB, 1982. p. 175-202.

Politica e racionalidade. Belo Horizonte: UFMG, 1984.

SMITH, Adam. A riqueza das nações. São Paulo: Abril, 1983 (Os Economistas). 
WEBER, Max. Sociologia. São Paulo: Ática, 1989.

Metodologia das Ciências Sociais. SãoPaulo: Cortez, 1992.

Recebido em 25 de agosto de 1994.

Reinaldo de Montalvão de Moraes Cunha, doutorando em Educação pela Universidade Federal do Ceará (UFC), é professor adjunto do Centro de Ciências da Educação da Universidade Federal do Piauí (UFP).

Modernity started a criticism of the old, causing the rupture between the public and the private, removing from the first the idea of universal ethical-moral principles, substituting them for interests. This modernity becomes the cuit of reason, under the purpose of pursuing interests linked to the instrumental reason. This fact justifies the "crisis" of values that contemporary societies undergo. Asa residi, (in the analysis and researches developed) it is extremely important to search for the rearrangement of knowledge beyond the instrumental reason. In this text, education is wiewed by the author as a principle able to shape politic will in the context of democratic production of culture. Education has the role of political mediator. The pedagogic act, considered a "desideologización" process, becomes an instrument for democratic shaping of the politic will: it removes through reflexion the wills that emerge from contradictions of reality and trough a discursive process discloses the occult face of ideology, producing wishes that show themselves trough concrete practical acts. Given the crisis of scientific paradigms in (he area of the sociology, especially in Political Science, the author denies theoretical approaches of authors who developed studies in education through the analysis of the relationships between Education 
in the Capitalist Social-Economical Structure. The understanding of the connection between productive forces and production relations where the political role of education is analized according to a dualistic model of social classes does not grasp any more the social and political reality of a "renewed" capitalism. This induces to (re) think Education.

La modernité a comencé la critique aux antiques en provoquant la rupture entre le public et le privé, en retirant du premier l'idée de principes éthico-morals universels en les remplaçant pour des intérêts liés à la raison instrumentale. Ce fait justifie la "crise" de valeurs qui touche les sociétés contemporaines. A cause de cela, dans le domaine de l'analyse et de la recherche, $c$ 'est très important la recherche de récomposition de savoirs pour au-delà de la raison instrumentale. En ce texte l'éducation est pensée par l'auteur comme principe formateur de volonté politique dans le contexte de production démocratique de la culture. Alors, / 'éducation trouve son rôle, c 'est-à-dire elle va devenir la médiatrice politique et s'assume catégoriquement comme un processus de désidéologisation. Ainsi, l'actepédagogique est devenu un instrument deformation démocratique de la volonté politique: l'éducation élimine par l'acte de réflexion les volontés qui naissent des contradictions de la réalité et à travers un processus discursif qui dévoile le côté oculte de l'idéologie en produisant des souhaits qui se manifestent en actes pratiques concrets de l'action politique. Devant cette crise des paradigmes scientifiques, dans le domaine de la sociologie, spécialement dans le champ politique, l'auteur refuse les références théoriques d'auteurs qui ont réalisé des analyses sur le même thème éducatif dans les sens d'examens et (re)examens des relations entre l'éducation et la structure économique-sociale capitaliste. La compréhension de ; a connexion forces productives et relations de production dont le rôle politico-social est analysé selon un modèle dualiste de classes sociales qui ne répond plus à l'actuelle réalité sociale el politique d'un capitalisme "renouvelé". Cela provoque en nous un (re)penser de l'éducation. 
La modernidad empezó la crítica de los antiguos promoviendo la ruptura entre el público y el privado, retirando del primer la idea de principios ético-morales universales substituiendo-lospor intereses. Así, la modernidad va a transformarse en el culto de la razón, en nombre del perseguir de intereses ligados a la razón instrumental. Este hecho justifica la crisis de valores queperpasa las sociedades contemporáneas. A causa de esto, en el campo de la análisis, de la pesquisa, es muy importante la busca de recomposición de saberes a los lejos de la razón instrumental. En este texto la educación es pensada por el autor como principio formador de volontadpolítica en el contexto de producción democrática de la cultura. Ahi, la educación encuentra su tarea de mediador político. Categorizado como proceso de desideologización, el acto pedagógico va a ser un instrumento deformación democrático de la volontad política: elimina por acto de reflexión las volontades que nacen de las contradicciones de la realidad y através de un proceso discursivo revela el lado oculto de la ideologia produciendo deseos que se manifestán en actos prácticos concretos de la acción política. Frente la crisis de paradigmas científicos en la area de la sociologia, especialmente en la de política, el autor rechaza los referenciales teóricos de autores que realizaran algunas análises del tema educación en el rumo de examenes y (re)examenes de las relaciones entre Educación y Estructura Economicasocial capitalista. La comprensión de la conexión fuerzas productivas y relaciones de producción onde el papel político de la educación es analizado según un modelo dualista de clases sociales que no responde más a la actual realidad social y política de un capitalismo (renovado). Esto instiga un (re)pensar de la Educación. 